\title{
Local Policy Risk and IPO Performance
}

This draft: December 3, 2018

\begin{abstract}
We investigate how the realignment in political landscape (local policy risk) increases IPO mispricing. Using the concept of corporate proximity to political power, we find that local policy risk amplifies adverse selection problems, which leads to higher underpricing. Economically, a shift on the political map from an area completely opposed to the ruling party to being completely aligned translates to $\$ 12$ million left on the table for the average issuer. While politically active firms successfully manage this policy realignment risk, the other firms bear majority of its consequences. We also demonstrate considerable heterogeneity on the impact of uncertainty emanating from the dynamic nature of the political landscape across industries, states, and firms. Lastly, we document that policy risk has a substantial adverse impact on the survival of IPO issuers.
\end{abstract}

JEL Classifications: G10; G14; G32; G39

Keywords: Initial Public Offering, Underpricing, Political Uncertainty, Political Proximity, Policy Risk 


\section{Introduction}

"When economists talk of political risk, they usually mean...national elections... But there is another kind of political risk: the temptation for governments of all political colours to change the rules, whether they relate to tax, the way that companies operate or how markets behave. And that risk has increased significantly since the 2008 crisis"

[Economist, Buttonwood, November 9, 2013]

Traditionally, politicians make decisions that alter the environment in which firms operate in, and they do so more often when the economy is weaker. This process could have a positive effect on asset prices if governments and regulatory institutions respond properly to such unanticipated economic shocks. As Pastor and Veronesi $(2012,2013)$ argue, this type of uncertainty can be a common feature of even the healthiest political process; yet, anecdotal evidence suggest that in the aftermath of the 2008-2009 global financial crisis, surges in policy initiatives - as reflected in a wave of government interventions - were a major contributing factor to the sluggish economic recovery (Economist, 2013). This observation has fueled an intense debate about whether government actions benefit the economy, a debate that is still ongoing.

Responding to this controversy, a budding literature documents that greater levels of policy uncertainty can have adverse effects on both financial and real activities. Regarding the financial implications, distortions in the firms' information environment, due to exogenous political shocks, make it more difficult for investors to accurately price a company, which in turn increases the cost of capital (e.g., Boutchkova et al., 2012; Brogaard and Detzel, 2015). As for the real effects, uncertainty increases the option value of waiting, making thus firms more cautious in their investment behavior and undermining their growth prospects (e.g., Julio and Yook, 2012, 2013; Jens, 2017).

The research on the pricing implications of the political environment has primarily focused on large, established corporations (Brogaard and Detzel, 2015; Pasquariello and Zafeiridou, 2014), giving far less attention to small, young, fast-growing, entrepreneurial firms such as those conducting an Initial Public Offering (IPO). We argue that a detailed examination of the empirical implications of political uncertainty on the pricing of newly listed firms is warranted as: (1) firms moving from start-ups to professionally managed companies are especially affected by (political) uncertainty shocks, since they do not have established track records and suffer from a "liability of newness" (Certo, 2003; Çolak et al., 2017); (2) IPOs constitute an important milestone for individual firms because their success largely determines the amount of cash raised, and consequently influences the ability of a firm with limited resources to propel its growth and solidify its competitive advantage (Kenney et al., 2012; Borisov et al., 2017); and (3) IPOs are also crucial for the aggregate economy because a vibrant market for Initial Public Offerings is a vital asset for the aggregate economy given its role in facilitating entrepreneurship, venture capital, job creation, and sustainable growth (Black and Gilson, 1998; Doidge et al., 2013). 
We endeavor to contribute to this literature by formulating the following questions. How do IPO investors perceive political realignment risk and what is the price the issuing firms pay for such risk? Do IPO issuers engage in actions to actively mitigate the potential adverse effects of this type of political uncertainty? To what extent does the impact of policy risk depend on firm-specific attributes, industry or even state policy-related characteristics? Finally, does the influence of such policy-related uncertainty extend beyond the first trading day?

The theoretical insights by Pastor and Veronesi $(2012$; 2013) suggest that political uncertainty commands a risk premium and depresses asset prices. Although several studies provide corroborating evidence to this proposition for SEOs (Brogaard and Detzel, 2015) and for IPOs (Colak, et al., 2017), there is no clear evidence on how local political realignment and the associated risks affect equity mispricing and issuance discount (underpricing). We show that local policy risk increases adverse selection costs for the IPO firms, which in turn is reflected in higher underpricing. More specifically, we examine how uncertainty about the impact of an administration's policies varies across different areas of the political map by utilizing the political alignment index (PAI) proposed by Kim et al. (2012), which exploits exogenous state-level variation in the degree of partisanship. The main advantage of this approach is that it acknowledges that election events do not completely resolve the political uncertainty, as decision agents would still not know which of the promised policies the newly elected politicians would eventually implement and how these policies would affect corporate outcomes (Antia at el., 2013). As such, it allows for the possibility that the well documented effects of electoral risk may extend beyond election cycles. ${ }^{1}$

To better understand why political alignment may affect the likelihood, the nature, and the impact of future government policies consider that the U.S. political landscape gets rearranged every two years, following Presidential and midterm elections. Post-election shifts in the political landscape result in changes to the degree of local politicians' partisan alignment with the President's party, affecting their access to political power. Accordingly, the resulting political discretion directly affects the effectiveness of the legislative activity, as it leads to the emergence of new items in the political agenda, on the one hand, and to increased potential favoritism of majority party politicians to some of their local constituents, on the other hand. Both of these channels, however, may have policy risk implications and economic welfare implications as well (Kim et al., 2012).

\footnotetext{
${ }^{1}$ One of the main empirical challenges in the political science literature lies in the selection of an appropriate measure of political uncertainty. In particular, one strand of the literature employs news-based measures (e.g., Gulen and Ion, 2016; Bonaime et al., 2018), such as the text-based uncertainty index of Baker et al. (2016). This measure allows for a continuous tracking of policy risk; nonetheless, it is subject to potential endogeneity problems because uncertainty is countercyclical (Jens, 2017). To separate the effects of political cycles from business cycles, other studies use discrete prescheduled events such as Presidential or Gubernatorial elections, as a plausible source of exogenous uncertainty (e.g., Boutchkova et al., 2012; Belo et al., 2015; Jens, 2017, and others). Yet, the inferences from these studies may be artificially precise because the passing of an election does not necessarily indicate the complete resolution of uncertainty surrounding future government actions (Brogaard and Detzel, 2015).
} 
With respect to the policy risk implications, several studies from the political science literature assert that greater political proximity enables policy makers to dominate senate and house committees in Congress, thereby enhancing their capacity of sponsoring, drafting, and passing new legislation (Malkiel, 1979; Anderson et al., 2003; Krutz, 2005). However, Fowler (2006) argues that when one party has full control, the extent of negotiations and the potential to limit the range of policy changes is lower than under divided governments. This implies that a unified government, or more broadly, greater political proximity to powerful politicians is associated with less predictable future outcomes. In support of this argument, prior studies show that, while greater partisanship leads to greater legislative interference, it also injects uncertainty regarding the redistribution of future growth opportunities among firms within an area (Ferguson and Witte, 2006; Füss and Bechtel, 2008).

In a similar vein, models of political risk show that changes in government policies exert an adverse market-wide effect that is largely non-diversifiable. For example, Pastor and Veronesi (2012, 2013) demonstrate that, in a setting where rational economic agents formulate decisions based on expectations about future policy initiatives; even market-benevolent policy makers can increase risk, if their future actions are surrounded by considerable uncertainty. In such a case, political uncertainty commands a risk premium and depresses asset prices. As such, while political uncertainty emanating from changes in the political map can shape a firms' information environment, its adverse impact is not the same across different areas of the political landscape, instead it should be pronounced in areas of greater political alignment.

Arguably, firms issuing public equity for the first time face a variety of constrains imposed by asymmetric information regarding the value of assets-in place and growth options. This translates to adverse selection problems, which in turn might substantially reduce the demand for IPO's shares, and consequently, the amount of proceeds. To mitigate such problems, IPO issuers may choose several mechanisms. One such mechanism is underpricing the issue, that is, selling the shares at discount. In a market characterized by heterogeneously informed investors, underpricing does not only stimulate demand and persuades informed investors to reveal private information about the offer (Benveniste and Spindt, 1989), but most importantly, it compensates uninformed investors for the winner's curse, as the latter bear the risk of holding too many bad stocks (Ritter, 1984, Rock, 1986).

Based on this discussion, one could anticipate that IPO firms located in areas with greater political alignment with the ruling party are exposed to more diverse implications of policy risk, and hence, suffer from severe adverse selection problems. In other words, political proximity should be related with greater IPO underpricing. Nonetheless, as mentioned above, political proximity may also have economic welfare implications. As several papers note, it is conceivable that the priorities and related actions of local politicians may be shaped by re-elections concerns (Mayhew, 1974; Mouw and Mackuen, 1992). From this perspective, one cannot rule out the possibility that political proximity may translate to favorable treatment of constituents and firms in the home states of local politicians (Duchin and Sosyura, 2012; Kostovetsky, 2015). 
If this is true, the need for discounting the issue in areas with greater political proximity should be, in fact, lower than otherwise. In turn, this implies that the relationship between political proximity and underpricing could be negative as well. As a consequence, IPOs with headquarters in areas with political proximity are exposed to a greater array of both threat and opportunities, thereby the net effect of political proximity on IPOs is theoretically ambiguous.

Using a large and comprehensive sample of U.S. IPOs from 2000 to 2016, we document a pervasive impact of political proximity on IPO underpricing. Specifically, we find that PAI is significant and positively related to initial aftermarket returns. Economically, our results also suggest that, ceteris paribus, a shift on the political map from an area entirely opposed to the President to being completely aligned increases the average local IPO firm's underpricing by $6.6 \%$, which, in turn, translates to $\$ 12$ million left on the table, on average.

Given the adverse effect of PAI on the amount of proceeds raised by the IPO issuers, one would expect that these firms do not remain irresponsive, but rather they may device corporate political strategies that provide differential access to information throughout the legislative activity in order to mitigate the negative consequences of policy risk. Consistent with the view that political money contribution constitutes a hedging tool against policy risk (Bradley et al., 2016; Gross et al., 2016; Wellman, 2017), we demonstrate that underpricing is not significantly associated with policy risk for firms that either lobby or make PAC contributions. This implies that politically active firms are able to offset (at least in part) the negative of exposure to policy risk.

To gain further insights into the link between policy risk and IPO performance, we conduct extensive cross-sectional tests. We, first, consider the external environment of the firm at both the industry- and the state-level. We find that the influence of policy risk is exacerbated for the IPOs operating in politically sensitive industries and weakened for IPOs with headquarters located in geographical areas characterized by higher values of economic freedom. As for the potential role of firm attributes, we show that the influence of policy risk on IPO first-day returns is more severe in hard to value firms.

Although our results are not sensitive to alternative fixed-effect specifications and influential states, we reinforce the robustness of our conclusions by employing additional policy-related risk proxies. Consistent with our baseline results, alternative policy risk measures based on the number of bills introduced in Congress by home state politicians, the economic policy uncertainty index of Baker et al. (2016) or the partisan conflict index of Azzimonti (2017) do not alter our main inferences. Finally, we also consider whether the implications of policy risk are long-lasting. IPOs originating from a state that is characterized by high policy risk have significantly greater return volatility for the first 12 months following the IPO. Also, survival and hazard models reveal that these IPOs have lower survivability rates.

Our work contributes to the flourishing research on the impact of policy uncertainty on stock mispricing and the cost of financing activities, in general. Recent works have explored the effect of policy 
risk on the equity market (Boutchkova et al., 2012; Kim et al. 2012; Pantzalis and Park, 2014; Brogaard and Detzel, 2015), the debt market (Francis, et al., 2014; Waisman et al., 2015; Bradley et al., 2016), as well as the options market (Goodell and Vähämaa, 2013; Kelly, Pastor, and Veronesi, 2016). The common theme of these studies is that capital markets are an informative gauge of the price of political uncertainty. Our novel contribution to this literature is that policy risk is also priced in the IPO market. Importantly, to the extent that government policies aim to stimulate the economy and encourage entrepreneurial activities, the IPO market provides a better setting to examine the impact of policy risk, as the success of an IPO is crucial for ensuring the long-term prospects of young and fast growing firms, and hence for maintaining a sustainable and healthy growth in the aggregate economy as well (Butler et al., 2016).

Moreover, by considering the role of policy risk we contribute to the literature on the determinants of IPO underpricing. Existing works in this area have studied, for instance, whether executive board characteristics (Filatotchev and Bishop, 2002; Higgins and Gulati, 2006,), gatekeepers (Bedard et al., 2008; Benveniste and Wilhem, 2008; Chaplinsky et al., 2017), underwriters (Carter and Manaster, 1990), venture capitalists (Krishnan et al., 2011) and information intermediaries (Cohen and Dean, 2005; Bajo and Raimondo 2017) influence IPO initial pricing. Relatedly, past studies further demonstrate that IPO outcomes have distinct geographic characteristics related to demographics and information advantages (O'Brien and Tan, 2015; Nielsson and Wojcik 2016). We provide further insights by demonstrating that the impact of geography on IPO valuation entails a significant political dimension.

Our paper also represents the first attempt (to our knowledge) to bring together the extant literatures on political uncertainty and real long-term IPO outcomes. Existing studies on seasoned firms use either elections (Jens, 2017) or aggregate uncertainty measures (Julio and Yook, 2012) to show that exogenous political shocks can be important for firm's ongoing economic survival. In the IPO context, Çolak et al. (2017) focus on electoral risk at the state level, and show that gubernatorial elections dampen the local IPO activity (IPO volume). Although we also exploit a state level measure of policy risk, our identification strategy permits us to extend this study along the following dimensions. We focus on IPO mispricing (underpricing) and IPO delisting rates. Furthermore, by focusing on the dynamic evolution of the political map as it emerges from federal and state-level elections, we essentially capture the exposure of IPO issuers to political uncertainty beyond election cycles. In doing so, we do not only provide additional insights on the consequences of a charged political climate but we also analyze the interplay of electoral and policy risk, and hence provide a broader view of the influence of the political environment in the IPO process. Furthermore, we find that the impact of policy risk is not limited to the first-trading day, but rather, it has long-term implications, as it adversely affects the survival of IPO firms.

Finally, this study contributes to recent discussions on the consequences of corporate political strategies. The extant literature argues that firms with superior access to policymakers throughout the legislative process have lower information asymmetry, which ultimately leads to more informed investment 
decisions (Faccio 2006; Goldman, et al., 2008, 2009; Wu et al., 2012; Correia, 2014; Tahoun, 2014). However, there is limited evidence on the benefits of access to information related to policy outcomes for IPO issuers. A notable exception is the study Gounopoulos et al. (2017), because it finds that contributions to political action campaigns or lobbying activities alleviate information asymmetry problems thereby relating negatively to IPO first-day returns. We complement and expand this study, as we show that one particular motive that justifies political activism for firms conducting an IPO is the reduction of the money left on the table, by hedging away the exposure to local policy risk. In this respect, our findings enhance our understanding regarding the underlying mechanisms through which corporate political strategies may create value.

The rest of the study is structured as follows. Section 2 presents the theoretical background and develops our hypotheses. Section 3 provides an overview of the sample selection procedure, while Section 4 describes the research design. Section 5 reports the descriptive properties of our sample and the main empirical findings. Section 6 evaluates the robustness of our results, and Section 7 presents the long-term implications of PAI. Finally, Section 8 concludes the paper.

\section{Background and Hypotheses Development}

In this section, we develop formally our hypotheses about the relationship between uncertainty induced by political proximity and IPO underpricing. To do so, we initially outline the theoretical background on why uncertainty about future government actions is relevant for asset pricing. Accordingly, we discuss how political proximity and policy risk are linked and how this relationship affects the pricing of IPOs.

\subsection{Theoretical Background and Empirical Challenges}

Pastor and Veronesi $(2012,2013)$ present a general equilibrium model for evaluating the influence that political uncertainty exerts on capital markets. In this framework, the authors interpret political uncertainty broadly as uncertainty about the government's future actions. Further, they hypothesize that governments do not behave as fully benevolent social planners, because they take into account the political costs associated with adopting a new policy. Since these costs are typically uncertain, investors cannot fully anticipate which policy the government is going to implement. In addition, the uncertainty about government's future actions is not fully diversifiable because it affects all firms. Therefore, political shocks introduced by government-induced policy changes can have a profound impact on financial markets, by raising discount rates and depressing asset prices.

Consistent with the notion that political uncertainty is harmful for the economy, the extant literature on the intersection of political science, finance and economics provides abundant supporting evidence. What is perhaps, more interesting in this inquiry, is the identification of an appropriate measure of policy 
uncertainty. For instance, Gulen and Ion (2016) and Bonaime et al. (2018) employ the aggregate text-based economic policy uncertainty index of Baker et al. (2016) and show that it adversely affects corporate investment and M\&A activity. However, Kelly et al. (2016) note that it is difficult to distinguish the cause from the effect because uncertainty is countercyclical, rising sharply in recessions and falling in booms.

To control for these confounding effects, other studies focus on electoral risk, that is, uncertainty surrounding political elections ( $\mathrm{Li}$ and Born, 2006; Julio and Yook, 2012; Boutchkova et al., 2012, to name but a few). Elections are popular measures of political uncertainty because they are exogenous prescheduled events. Nonetheless, they only partially solve the uncertainty surrounding political outcomes, as economic agents would still not know which of the promised policies the newly elected politicians would eventually implement and how these policies would affect corporate outcomes (Gulen and Ion, 2016).

\subsection{Local Political Proximity and Policy Uncertainty}

In this study, we disentangle the causal effects of policy uncertainty by relying on the concept of local proximity to political power, that is, the degree of political alignment of local politicians with the ruling party. To do so, we focus on the US market and specifically on geographical ties at the state level between firms and powerful politicians. In this respect, political proximity can be regarded as the degree of political and ideological alignment between the President and its administration with the federal government and the state governments (Kim et al., 2012). Based on this reasoning, we postulate that in order for the local political proximity to lead to higher policy uncertainty, four conditions must be true: (1) there is a direct link between legislative uncertainty and political proximity; (2) local politicians must have sufficient motives to direct the set of preferred policies toward particular geographic areas; (3) changes to state-level policies must have a material impact on the business environment; and (4) policy risk associated with local political proximity is exogenous and cannot be fully diversified away.

Regarding the first condition, Kim et al. (2012) argue that a major source of policy risk is uncertainty surrounding the legislative activity. This argument is based on the heart of the political function, as the process of converting policy agenda items to congressional bills involves numerous amendments or alterations and, of course, requires a significant amount of time for the final acceptance by a majority in both chambers of Congress and the President. ${ }^{2}$ Importantly, legislative interference results in the emergence of new policies, thereby leading to less predictable economic outcomes. As a result, either due to the inherent complexity of the legislative process or because it alters the business environment, legislative activity injects uncertainty into the markets. In support of this view, Malkiel (1979) and Ferguson and Witte (2006) suggest Congressional regulatory activity as a proxy of policy risk, since it increases return volatility and hampers economic performance. Also, it is interesting to note that the study of Cohen et al. (2013) shows that

\footnotetext{
${ }^{2}$ As shown in the Internet Appendix (Table 3), in our sample there is a clear positive link between PAI and legislative activity, given that higher values of PAI are associated with more bills introduced and passed.
} 
congressional bills have a significant impact on firms, though the markets seem to have a difficulty in assessing the impact of these bills.

On the other hand, the capacity to shape the political agenda is a function of political partisanship. Fowler (2006) finds that when the executive and legislative branches in Washington are not divided (i.e., when the government is unified and has full control) the possibility of policy changes is higher. In this regard, access to political power enables policy makers to dominate the senate and house committees in congress and exert much greater influence sponsoring, drafting, and passing new legislation (Anderson et al., 2003; Krutz, 2005). Combining all the above, a natural conclusion is that while greater proximity to political power increases legislative effectiveness, it induces policy uncertainty into the firm's environment, as it facilitates policy initiatives, thereby making it harder for investors to assess what kind of policies are going to be adopted and what their impact will be on firm's future prospects.

With respect to the second condition, Mayhew (1974) and Mouw and Mackuen (1992), argue that, since reelection serves as the primary motivation of legislators, a greater array of policy initiatives will be directed towards firms and constituents of the legislators' home states. As a consequence, the policy risk associated with political alignment will rise not only with the range of possible future policies but also with the likelihood that policy initiatives will be targeted toward specific geographic areas (Roberts, 1990; Jayachandran, 2006). This is particularly important given that empirical studies suggest that local political connections may have an impact on constituents firms' performance. For instance, Faccio and Parsley (2009) document performance declines following sudden deaths dominating the firms' home area, whereas Cohen, et al. (2011) show that while changes in congressional committee chairmanship result in positive fiscal spending state-level shocks, they dampen corporate investment activity. ${ }^{3}$

As for the final condition, it is worth noting that the U.S. political map is redrawn every 2 years following federal and state-level elections. The resulting changes in the political landscape serve as a plausible source of exogenous uncertainty because they affect all firms within each state, regardless of the firms' efforts to actively seek direct political connections or not. Geographically, such political shifts induce dynamism in the firms' central location, despite that it is fixed over time. This dynamism makes it more difficult to assess the impact of future policies across different areas and limits the ability of firms to diversify policy risk.

\footnotetext{
${ }^{3}$ Besides the existing academic evidence, two indicative examples might illustrate why actual changes in state policies matter for firms. In 2011, widespread shortages labour shortages in the agriculture, hotel, construction and fishing industries were caused due to the enacted immigration law (HB 56) in Alabama because it punished businesses who hired illegal immigrants [How America's harshest immigration law failed, MSNBC, Benjy Sarlin, December 16, 2013]. Whereas, in 2013 the dispute between Walmart and the District of Columbia's City Council about the minimum wage jeopardized the viability of three stores mid-construction and the initiation of three additional stores [Walmart wins again as Washington D.C. mayor vetoes $\$ 12.50$ minimum wage, Forbes, Janet Novack, September 12, 2013].
} 


\subsection{Political Proximity and IPO Underpricing}

The preceding discussion suggests that the extent by which the chain of political authority that links federal and state governments is unbroken, the decision to invest in a firm located in an area where elected politicians are aligned with the President and its administration along ideological and party lines could directly be affected by policy risk. If this indeed is the case, one would expect that political proximity could undermine the firm's ability to raise external financial capital, because investors would demand a higher premium in order to bear such additional risk. ${ }^{4}$ Consistent with this interpretation, Kim et al. (2012) show that firms located in states of high political proximity experience higher stock returns commensurate with higher political risk premium. Similarly, Bradley et al. (2016) find that the political alignment of a firms' home state is positively associated with the cost of debt, whereas Gross et al. (2016) document that political proximity increases the opaqueness of the firms' information environment and the volatility of future operating profitability.

Extending the above reasoning to the primary equity market, we posit that uncertainty about policies emanating from shifts in political geography should influence the investors' perception about the prospects of IPO firms as well. The IPO process is an important strategic threshold in the lifecycle of an entrepreneurial firm because it provides access to the resources necessary to spur its growth (Lowry et al., 2017). However, it is also the first time where the ownership and control of the firm is separated, increasing adverse selection costs arising from information asymmetry problems between managers and investors, due to the lack of established track records (Certo, 2003). Accordingly, information asymmetries regarding the value of assetsin-place and growth options of IPO issuers could heighten investors' concerns about the intrinsic value of the firm.

To mitigate this problem of adverse selection, IPO issuers might offer their equity at discount. Several key theories of IPO pricing support this intuition and predict that an investment bank's pricing of an offering should be related to the level of information asymmetry surrounding the firm (for a review, see Loughran and Ritter, 2004). For example, Beatty and Ritter (1986) envisage a market characterized by heterogeneously informed investors, i.e., both informed and uninformed investors, and predict that offer prices must be discounted on average, either in order to compensate for the uninformed investors' winners curse (Rock, 1986) or to persuade informed investors to truthfully reveal their information (Benveniste and Spindt, 1989).

Since information asymmetry is one of the main drivers of IPO underpricing (Ljungqvist, 2007), any factor that exacerbates this problem should affect the investors' perceptions about the IPO value. In this respect, policy uncertainty is particularly relevant because it can aggravate the associated adverse selection

\footnotetext{
${ }^{4}$ The notion that political uncertainty exerts a negative financial effect on firm is supported by a series of studies on the impact of electoral risk on the cost of capital. For equity related capital, Pantzalis et al. (2000) and Li and Born (2006) find abnormally high stock returns during periods of elevated political uncertainty, whereas Santa-Clara and Valkanov (2003) show that equity risk premium varies with political cycles. For debt-related capital, Francis et al., (2004) find that greater political uncertainty imposes additional costs and more stringent non-price terms on bank loan contracts. Similarly, Gao and Qi (2013) show that municipal bonds yields rise around U.S. gubernatorial elections.
} 
costs. This could happen because exposure to policy risk deteriorates the firm's economic environment, making it more volatile and less transparent, reducing the effectiveness of external monitoring and creating incentives or opportunities for managers to engage in suboptimal behavior.

Rational investors are likely to anticipate these potential agency problems, especially for firms for which policy uncertainty is prevalent in their domiciled states. Accordingly, they will price-protect themselves by demanding a higher compensation for bearing such risk (Michaely and Shaw, 1994). This will be reflected in a greater cost of equity capital and lower offer prices, leading thus, to higher IPO underpricing. These observations yield our main hypothesis:

Policy Exposure Hypothesis: Policy risk emanating from higher political proximity exacerbates adverse selection problems associated with information asymmetry and thus leads to greater IPO underpricing.

On the other hand, we cannot rule out the possibility that political alignment can also have welfare implications. In fact, this conjecture is motivated by studies that regard politicians as vote-plurality maximizers. These studies model the importance of the President and its cabinet in shaping economic policies and find that government spending is allocated based on geographic importance (Downs, 1957; Tullock, 1976; Johnston, 1977, 1980). In a similar vein, the "loyal voter" theories assert that parties allocate a disproportionate amount of resources (government spending projects and programs) to electoral areas that benefit their supporters (Kramer, 1966; Cox and McCubbins, 1986; Ansolabehere and Snyder, 2006).

Consequently, it would not be unexpected to find that political proximity can be reflected in a more lenient treatment to electorally important firms (Heese, 2015). Not surprisingly, some empirical evidence confirms that this inclination was evident in the case of government bailouts during the 2008 financial crisis, where geopolitical ties influenced the allocation of assistance under the Troubled Asset Relief Program (Duchin and Soyura, 2012; Kostovetsky, 2015). Based on this reasoning, we anticipate that IPO firms located in areas with strong control of the ruling party might be able to gain additional benefits in the form of enhanced growth opportunities or competitive advantages, both of which imply lower discounting. This discussion yields our alternative hypothesis:

Favorable Treatment Hypothesis: Political favoritism stemming from greater political proximity leads to higher and more certain future payoffs, thereby mitigating adverse selection costs associated with information asymmetry and IPO underpricing.

\section{Sample Selection and Methodology}

Our sample selection starts with retrieving all initial public offerings (IPOs) between 2000 and 2016 from the U.S. Common Stock Data File of Securities Data Company (SDC) database. Consistent with the 
literature (e.g., Loughran and Ritter, 2004), we apply standard IPO filters to exclude foreign issues, unit offerings, reverse LBOs, spinoffs, closed end funds, real estate investment trusts (REITS), royalty trusts, financial institutions, limited partnerships, American Depository Receipts (ADRs), as well as all IPOs with an offer price below \$5.00. We obtain IPO background and issuance information from the SDC, including the issue data, offer price, total proceeds raised, whether the firm is backed by venture capital and the prestige of underwriters. For underwriter prestige ranking, the study employs Loughran and Ritter's (2004) measures of underwriter quality.

We also utilize IPO prospectuses from Securities and Exchange Commission (SEC)'s EDGAR in order to assign firms to geographic location (states or regions) based on headquarter or home office address information. Accounting data are retrieved from the Compustat database, and public trading prices are obtained from the Center for Research and Security Prices (CRSP). After merging the IPO data with the corresponding accounting and stock market information and eliminating observations with missing values, we end up with 1,639 IPO firms.

Data regarding the external political environment are collected from various sources depending on the type of election. Starting from the state where the firm's headquarters is located, we gather state-level elections results from different volumes of Taylor's Encyclopedia of Government Officials: Federal and State Elective Officials to identify the party affiliation of the majority of a state's legislative body. Results for gubernatorial and congressional elections are obtained from Dave Leip's Atlas of U.S. Presidential Elections (http://uselectionatlas.org). Election results for the U.S. House of Representatives were extracted from the website of the Office of the Clerk (http://clerk.house.org). Where necessary, information about the majority in both chambers of the Congress were complemented by the Biographical Directory of the United States Congress (http://bioguide.congress.gov). Finally, state-level data, such as real GDP growth rate, personal income, and unemployment rate are extracted from the Regional Economic Accounts Database provided by Bureau of Economic Analysis (BEA).

\section{Research Design}

\subsection{Measuring Proximity to Political Power}

In this study, we employ the Political Alignment Index (PAI) proposed by Kim et al. (2012) to measure the access of local firms to the center of political power (i.e., Washington, D.C.). PAI measures a firms' proximity to political power as it reflects the percentage of state's representatives in the Senate and House chambers of the Congress that belong to the President's party as well as the degree to which the presidential party controls the states' political institutions (i.e., the governorship and state legislature). It is a state-year variable, and in its main form, it is calculated by assigning equal weight to the portions of each of the state's delegations in the two chambers of the Congress that are aligned with the ruling party and the president's party control of the states' political institutions, as follows: 
$P A I=\frac{1}{4} *$ Senators $+\frac{1}{4} *$ Representatives $+\frac{1}{4} *$ Governor $+\frac{1}{4} *\left(\frac{1}{2} *\right.$ State Senators $+\frac{1}{2} *$ State Representatives $)$

where Senators is the percentage of the state's two senators in the U.S. Senate that belong to the President's party. Representatives is the fraction of the state's House representatives in Washington that belong to the President's party. Governor is a dummy variable which takes the value of one if the governor belongs to the same party as the President, and zero otherwise. State Senators is a dummy variable equal to one if more than $50 \%$ of the state senate belong to the President's party, and zero otherwise. State Representatives is a dummy variable equal to one if more than $50 \%$ of the state house belong to the President's party, and zero otherwise.

To evaluate the robustness of the PAI effect, we consider alternative measures of proximity to political power. Following Antia et al. (2013) and Kim el al. (2012) we experiment with two PAI variants by dropping the state's legislatures components (ModifiedPAI 1) and the state governors component (ModifiedPAI 2) and assigning equal weights to the remaining components:

ModifiedPAI1 $=\frac{1}{3} *$ Senators $+\frac{1}{3} *$ Representatives $+\frac{1}{3} *$ Governor

ModifiedPAI2 $=\frac{1}{2} *$ Senators $+\frac{1}{2} *$ Representatives

Since the value of PAI changes every two years, an alternative modelling strategy that may better captures the causal effect of shifts in the political landscape, is to investigate how changes of PAI instead of the level of PAI affect IPO initial returns. In this case, the variable of interest is the annual change of PAI for every state, namely, $\triangle P A I$. Finally, we consider a much broader PAI definition that accounts for geographic regions' instead of states' political alignment with the President and its administration (Regional PAI). In doing so, we classify states into four regions (West, Midwest, South, and Northeast) and average the PAI values across all states in each region. ${ }^{5}$

\subsection{Empirical Model}

The major focus of this study is to estimate the relation between proximity to political power and IPO underpricing. We test this relation between policy risk and initial returns to investors using multivariate methods controlling for firm, IPO and state characteristics. We use ordinary least squares (OLS) models and cluster standard errors at the state-level. We also include industry, state, and year fixed effects to mitigate omitted variable bias problem. In accordance with our developed hypothesis, our model takes the following form:

\footnotetext{
${ }^{5}$ West includes AK, AZ, CA, CO, HI, ID, MT, NM, NV, OR, UT, WA, WY; Midwest includes IA, IL, IN, KS, MI, MB, MO, ND, NE, OH,SD, WI; South includes AL, AR, DE, FL, GA, KY, LA, MD, MS, NC, OK, SC, TN, TX, VA, WV; and Northeast includes CT, MA, ME, NH, NJ, NY, PA, RI, VT.
} 
Our dependent variable is underpricing. The main variable of interest is the political alignment index (PAI) and is used as our main proxy of policy risk. We expect PAI to be positively related to underpricing if local policy uncertainty exacerbates the adverse selection problem. Alternatively, PAI should reduce initial IPO returns if proximity to political powers enhances an average firm's growth opportunities or reduces information asymmetry problems.

In addition, we control for offering and company characteristics that prior literature identifies as potential determinants of underpricing. We use firm age as a surrogate for risk. The underlying assumption is that firms with longer operations have proven their dynamism against the changes of the market and thus constitute safer investments (Carter et al., 1998). We use total proceeds at the time of listing as a proxy for firm size and visibility. We expect that firms with higher IPO proceeds exhibit less underpricing, consistent with the idea that large firms suffer less from information uncertainty problems than small firms. However, Gounopoulos et al. (2017) show that firms with higher IPO proceeds may be more underpriced.

Dolvin and Jordan (2008) suggest that the increased proportion of shares held by managers, namely, overhang is positively associated with high levels of underpricing. Also, Loughran and Ritter (2002) use market return as a measure of investor sentiment and document that it is a positively related with IPO initial returns. Moreover, Lee and Wahal (2004) argue that while financial intermediaries, such as underwriters and venture capitalists (VCs) play a certification role in the IPO process, they also have strong incentives to improve the first-day returns for the new shareholders. To account for the role of these intermediaries, we control for the reputation of the underwriter and the presence of venture capitalists.

Following Gounopoulos et al. (2017) we include earnings per share (EPS) in order to capture the influence of profitability tendencies in the year trailing to the IPO on underpricing. Also, prior studies show that immediate aftermarket returns depend on the level and nature of riskiness of the firm's external operating environment (e.g., Loughran, 1993; Loughran and Ritter, 2004). To this end, we consider whether IPO firms were in the Internet and Technology sector or incorporated in Nasdaq. Besides typical company characteristics, we also control for GDP growth rate, personal income and unemployment rate at the state level, since exposure to policy risk may be partially determined by the state's economic fundamentals (Bradley et al., 2016; Çolak et al., 2017).

\section{Empirical Results}

\subsection{Descriptive Analysis}

Table 1 presents the distributional statistics for the IPO activity, underpricing and the political alignment index. Panel A of Table 1 focuses on the time-series dimension, while Panel B reports how these measures vary across industries. An inspection at Panel A reveals that the number of IPOs and the level of 
underpricing tend to decrease after stock market and/or economic crises, as indicated by the Dot-com bubble and the Credit crunch in 2000 and 2007, respectively. An explanation of this behavior lies in the sensitivity of the investor sentiment to economic shocks (Lee et al., 1991; Loughran and Ritter, 2004) and the so-called "strategic waiting" phenomenon (Çolak and Gunay, 2011), both of which affect the timing of IPOs. In contract, PAI exhibits a rather consistent behavior over time, except in the year of the Dot-com bubble burst (2001) and the years surrounding the Credit crunch (2007-2008).

Panel B of Table 1 classifies IPO firms in sectors and reveals a relatively high concentration in the chemical products, computer equipment and services sectors. The food products and entertainment services sectors have the lowest representation of IPO firms. Consistent with the IPO literature (e.g., Ritter and Welch, 2002), technology firms, such as those operating in the computer sector, are more risky, and as a consequence, they experience higher underpricing than firms operating in less opaque environments, such as utility firms. Thus, as IPO first-day returns vary across both industries and time, it is essential to control for unobservable industry and time effects in our regressions. Regarding the values of PAI, it is interesting to mention that, the largest values can be found in chemical and manufacturing industries, whereas the lowest values are in the entertainment sector. Panel $\mathrm{C}$ presents the means of PAI, underpricing and IPO activity by state. Firms headquartered in 4 states (California, Texas, Massachusetts, and New York) represent around the one half of our sample. Also, there is considerable variation in PAI and underpricing across states. ${ }^{6}$

Table 2 reports the summary statistics of PAI and IPO initial aftermarket returns. Panel A suggests that PAI is higher during Republican presidencies, with a mean value of 0.51 over the 0.45 of Democratic presidencies. Panel B indicates that the average first-day returns are higher during Democratic presidencies, which accords with the asset pricing tests of Kim et al. (2012). Panel C presents the average PAI in the home states of the Presidents, Vice Presidents, and Speakers of the U.S. House of Representatives. Consistent with the notion of proximity to political power, the home states of Presidents and Vice Presidents have greater PAI than the home states of Speakers. An exception, however, is the home state of Barak Obama which ranks lower to the home state of its Vice President (Joe Biden) in the same period.

Table 3 shows the mean values of firm fundamentals and state-level characteristics for firms located in states with low and high PAI, respectively. Panel A clearly indicates that firms with headquarters in states with high proximity to political tend to experience higher levels of IPO first-day returns, providing thus, preliminary support to our main hypothesis. Panel B further elaborates on this issue by providing illustrating examples of how IPO underpricing varies in states with low and high proximity to political power. For instance, Linkedin had an underpricing of $109.44 \%$ and operates in California, which is a state with very high PAI (0.91). On the other hand, Dov Pharmaceutical experienced a negative underpricing of $-21.50 \%$ (i.e., overpricing) and operates in New Jersey, which is a state with a relatively low value of average PAI (0.12). ${ }^{7}$

\footnotetext{
${ }^{6}$ Figure 1 in the Appendix further illustrates how the average PAI varies across states.

${ }^{7}$ See Table 4 in Internet Appendix.
} 
As for the remaining firm characteristics, we find that the IPO issuers located in states with high PAI are younger and have more financial leverage, compared to firms in states with low PAI. However, the former firms have higher proceeds from the offering and are less profitable. Interestingly, these firms are regarded as risky because they operate in the internet and technology sector, and have more reputable underwriters and venture-backing than low PAI firms. Lastly, Panel B indicates that in states with high proximity to powerful politicians GDP growth rate, personal income and unemployment rate are higher than otherwise.

\section{2 Multivariate Regressions}

\subsubsection{The Effect of Political Alignment Index (PAI) on IPO First-Day Returns}

Table 4 presents the results of our OLS regression tests on the association between the political alignment index and IPO underpricing. Column (1) displays the results for PAI. Columns (2) and (3) consider two variants of PAI, while Column (4) presents the results for the regional PAI.

Column (1) documents a strong and significant positive relation between PAI and initial aftermarket returns, suggesting that, after controlling for firm-specific and state-level economic factors, PAI tends to increase IPO first-day returns. This is a sizeable effect in economic terms; a unit increase of the PAI score (i.e., a shift on the political map from an area completely opposed to the president to being completely aligned) increases the average local IPO firm's underpricing by $6.6 \%$, which, in turn, translates to $\$ 12$ million left on the table. Similar conclusion can be obtained by looking the coefficients of the PAI variants and the regional PAI. Overall, the results from columns (1)-(4) are supportive of the policy exposure hypothesis and consistent with the notion that the information environment of an average local firm deteriorates when its state's position on the political map shifts toward the centers of political power.

The findings pertaining to the control variables are interesting in their own right. The coefficient on age is positive but insignificant, which contradicts with the notion that long-lived companies have lower uncertainty. Similarly, leverage and EPS tend to increase initial returns to investors, however, their coefficient is indistinguishable from zero. Likewise, the coefficient on proceeds raised is positive but marginally significant. Since size should presumably lead to less, rather than more underpricing, this may reflect the need to attract more uninformed investors via a discount. We obtain a positive and highly significant coefficient on overhang, which is in line with Dolvin and Jordan (2008). Consistent with Loughran and Ritter (2004), we report that the underwriters as well as the venture capitalists contribute positively to immediate aftermarket returns. Also, technology stocks tend to have higher underpricing, whereas internet stocks' underpricing is not significantly different from rest of the sample. We obtain a positive and highly significant coefficient on market return, which is consistent with Loughran and Ritter (2004). Finally, the coefficients of the state-level variables do not significantly relate to underpricing. 


\subsubsection{Do IPO Firms Hedge Policy Risk by Engaging in Active Political Strategies?}

Having established that PAI is positively associated with IPO initial returns, it is natural to ask how political alignment - as a source of policy risk - is related with corporate political activism. It is welldocumented that firms adopt active corporate political strategies in order to establish political connections, so that they can reap private benefits. These connections often take the form of adding politicians to the board of directors (Goldman et al., 2008, 2009), financial contributions to election campaigns and lobbying expenditures (Correia, 2014), top management's past service in the government or military positions (Wu et al., 2012), and equity ownership by influential politicians (Faccio 2006; Tahoun, 2014). While these corporate political strategies vary in terms of nature and effectiveness, they aim to establish a direct relationship between firms and policy maker that brings preferential political treatment and gives more information on the legislative process.

With respect to the uncertainty emanating from political proximity, Antia et al. (2013) find that firms use political strategies to lower local policy risk, as they adjust their lobbying expenditures in reaction to changes in political geography. Bradley et al. (2016) document that local political proximity increases the cost of debt, but only for firms not engaging in lobbying and/contribution to PACs, whereas Gross et al. (2016) document that policy risk exerts a significant influence on financial reporting choices and the firm's information environment when firms are not politically active. Similarly, Wellman (2017) finds that political connections (partially) offset the negative relation between investment and political uncertainty.

Therefore, from a resource perspective, corporate political strategies can be viewed as an intangible asset, a source of political intelligence that enhances firms' ability to better time its responses to political developments (Amore and Minichilli, 2018). If indeed the market regards this form of political capital as an indication of a firm's capability to deal with the complexities of the political system, this form of political activism should also mitigate to some extent the information asymmetries in IPOs. Gounopoulos et al. (2017) support this view as they show politically active IPO firms experience lower underpricing. Building on this study, we further hypothesize that the underlying mechanism driving the relationship between underpricing and political donations is the degree of exposure to policy risk. As a consequence, we posit IPO issuers stand to ultimately gain from corporate political strategies because these courses of action decrease the exposure to policy risk.

We put this hedging hypothesis to test by looking whether companies engage in political money contributions (i.e., if firms either lobby or make PAC contributions, $\mathrm{PMC}=1$ ) or not $(\mathrm{PMC}=0)$. Then, we examine if political money contributions (PMC) can effectively protect IPO firms from policy risk by performing OLS regressions in the PMC and non-PMC subsamples, respectively. ${ }^{8}$ As expected, Panel A of

\footnotetext{
${ }^{8}$ Data regarding the lobbying activities and PAC contributions are carefully hand collected from OpenSecrets. Our lobbying and PAC sample covers a 17-year period from January 2000 to December 2016. When we match our IPO sample with the OpenSecrests database, we identify 158 firms with lobbying experience and 53 PAC-active IPOs. Additionally, the number of firms with political money contributions (PMC) is 181. See Internet Appendix for more information about the distribution of PMC.
} 
Table 5 shows that the association between policy risk and IPO underpricing is not statistically significant if firms actively pursue political strategies, while the influence of policy risk on underpricing is strengthened in the absence of political money contributions.

However, a potential problem with these results is sample selection bias. Among others, Gounopoulos et al. (2017) document that the decision to engage in political actions is not random, but rather, it is more likely to be related with the factors reflecting the resource availability of firms as well as the external environment. In this case, the standard errors in the models previously estimated could be biased, that is, overstated or understated because firms tend to self-select to participate in political activities. Since, in our sample only $11 \%$ of the IPO firms engage in political money contributions, we cannot rule out the possibility that our inferences are subject to concerns related to potential selection bias.

To alleviate these concerns, we follow two distinct strategies. First, we use the propensity score matching (PSM) procedure. Our identification strategy is to reduce the bias by comparing the PAI effect on underpricing (outcome) between firms that are comparable only in array of factors except political money contributions. To obtain the closest equivalent for each politically active firm (treatment group), we run a logistic model with a set of covariates that may affect the likelihood of engaging in corporate political strategies and match non-PMC firm (control group) to each PMC firm (treatment group) on a one-to-one basis based on the estimated propensity score. ${ }^{9}$ Using this procedure, we are able to identify a sufficiently close match for 149 of our treatment observations (out of 181), resulting in a sample comprising of 298 treatment and control observations. We then re-test our hedging hypothesis in the treatment and matched subsample, respectively. Our results in Table 5, confirm that the relation between PAI and IPO underpricing is significant only for firms that do not engage in political money contributions.

Lastly, we attempt to control for self-selection bias in an alternative way by utilizing the two-stage Heckman (1979) procedure. In doing so, we initially run a logistic regression where the dependent variable is PMC and the independent variables are the same as in the PSM methodology. Then, we save the residuals from this logistic regression and construct the Inverse of Mills Ratio for PMC. In the second-stage model we include the Inverse of Mills Ratio in the main model for IPO first-day returns and report the results of the OLS regressions in columns (3) and (4) of Panel B (Table 5).

As shown by column (3), the positive coefficient of the Inverse Mills Ratio suggests that ignoring a firm's unobservable characteristics that affect propensity to participate in political actions would result in overestimating the impact of PAI on underpricing. Nonetheless, the coefficient of PAI for PMC firms remains insignificant. With respect to non-PMC firms, the insignificant Inverse Mills ratio in column (3) indicates that selection bias for non-PMC firms does not seem to be a concern, whereas the PAI effect on underpricing remains positive and highly significant. Overall, the results from the models that account for

\footnotetext{
${ }^{9}$ To allow for a better match between connected and non-connected firms we include all covariates from the baseline regression. Also, to identify the firms that provide the closest match, we perform the nearest neighbor matching method for firms in the same year.
} 
sample selection bias using the Heckman's procedure are still supportive of the policy exposure hypothesis and consistent with the notion that direct political connections either in the form of PAC contributions or lobbying expenditures mitigate the effects of policy risk on underpricing.

\section{Robustness Analyses}

The results thus far, show that political proximity is positively associated with initial (IPO) aftermarket returns, which is consistent with the hypothesis that political proximity leads to higher policy risk. This interpretation is reinforced by the fact that firms pursue active political strategies in order to hedge policy risk emanating from local political proximity. Otherwise, political alignment should play a role in delivering political favors, and hence we would expect to find a significant negative relation between PAI and IPO underpricing, especially for firms pursuing corporate political strategies.

In this section, we aim to gain additional insights into the PAI effect and to further establish the direction of causality by conducting a series of additional tests. We begin our analysis by examining whether the impact of the policy risk is a function of the infrastructure of states, industries and firms, respectively. Finally, we corroborate the robustness of our baseline results by employing alternative proxies for policy risk and by considering their sensitivity to various industry specifications.

\subsection{Industry and State Infrastructure}

To examine whether and how industry characteristics exacerbate or attenuate the positive effect of PAI on IPO underpricing, we consider the sensitivity to political uncertainty at the industry level. Julio and Yook (2012) and Jens (2017) show that the negative effect of political risk on firm investment is stronger in politically sensitive industries. Boutchkova et al. (2012) further demonstrate that equity return volatility is stronger in industries that are sensitive to political shocks. We extend this line of reasoning by stating that the PAI effect on IPO valuation is pronounced for firms operating in politically sensitive industries, since these firms are more likely to experience regulatory changes, and hence greater policy uncertainty (Kostovetsky, 2015). ${ }^{10}$

With respect to the state infrastructure, it is well-documented that government intervention is more severe for firms that are subject to weak institutional constraints (see, e.g., Shleifer and Vishny, 1994, 1998). Extending this reasoning, we posit that if government intervention in the form of regulatory initiativesinjects uncertainty into the business environment, the ability of politicians to (adversely) affect the economic environment should be diminished in areas with higher institutional quality. To operationalize institutional

\footnotetext{
${ }^{10}$ Following, Herron et al. (1999) we define firms operating in Tobacco Products, Pharmaceuticals, HealthCare Services, Defense, Petroleum and Natural Gas, Telecommunications and Transportation industries as politically sensitive, whereas the identification is based on the Fama French 48 industry classification scheme. We then create a dummy variable which is equal to one for firms that belong to one of the politically sensitive industries.
} 
quality, we use the state economic freedom index from the Fraser Institute. ${ }^{11}$ The index is constructed to capture three main elements: the size of government of a particular state, discriminatory taxation, and regulation. By definition, a higher degree of economic freedom is inversely related with the size, and regulatory intervention of local governments, which, in turn implies a lower ability of politicians to shape the broader environment in which the firm operates. In light of this, higher values of economic freedom translate to lower policy risk, and hence, a weakened positive impact of PAI on IPO initial returns.

Table 6 presents our findings on the mediating role of industry and state factors. Specification (1) indicates that the PAI effect on underpricing is stronger when firms operate in politically sensitive industries, whereas specification (2) demonstrates that in states characterized by high institutional quality the relationship between policy risk and initial aftermarket returns is weakened.

\subsection{Firm Characteristics}

We now turn our attention on whether the effect of PAI on underpricing varies with firm characteristics related to information asymmetry problems. In particular, we investigate whether the effect of political alignment on IPO initial returns varies across firms in terms of business models, maturity, and agency problems.

Prior studies show that technology firms differ substantially from other firms, since they operate in less established industries and are subject to an inherently higher degree of uncertainty (Schenone, 2005). Also, they face higher failure rates due to huge organizational costs of commercializing high complexity technologies (Loughran and Ritter, 2004). Similarly, younger firms are less visible, have shorter track records and less developed administrative capabilities than more established firms (Lowry and Murphy, 2007). Since policy risk worsens information asymmetry problems, we expect that the PAI effect on underpricing is pronounced in technology and younger firms.

Finally, to proxy for agency problems we utilize the magnitude of free cash flows. Mishra (2014) argues that firms with high cash flow are likely to have the most serious agency problems, whereas firms with low cash flow are likely to have the least severe agency problems. Since, agency conflicts exacerbate information risk and adversely affect the firm's ability to handle increased uncertainty, we anticipate that the influence of local policy risk is stronger in firms with agency conflicts.

Columns (1) to (4) of Table 7 show that the impact of PAI is pronounced among technology and younger firms, which is consistent with the notion that the adverse effect of uncertainty is strengthened among hard-to-value firms. In a similar spirit, columns (5) to (6) reveal that the positive influence of policy risk on underpricing is also driven by agency issues in manner consistent with our prediction.

\footnotetext{
${ }^{11}$ We extract historical information on state economic freedom from the Fraser Institute (http://www.freetheworld.com).
} 


\subsection{Alternative Ways to Measure Policy Risk}

Throughout our analysis, we resorted to the political alignment index developed by Kim et al. (2012) as our main proxy of policy risk. In this section, we further evaluate our main hypothesis using alternative indicators related to legislative activity. We initially consider the number of bills introduced in Congress by home state politicians for a given year (BilNum). Kim et al. (2012) argue that while the legislative efforts of influential politicians are mainly directed toward their home constituents, the legislative process, i.e., bill passing, is typically lengthy, generating thus, policy uncertainty. Further, we acknowledge that the legislative activity may be driven by factors that extend the boundaries of a particular state. The monthly economic policy uncertainty index (EPU) constructed by Baker et al. (2016) is a national index, thereby reflecting broader economic forces that shape the administration's policy agenda. ${ }^{12}$ Following Bradley et al. (2016), we employ PolRisk1 replacing PAI with BilNum and PolRisk2 and PolRisk3 by multiplying PAI with EPU and BilNum, respectively, in an attempt to capture the overlapping effects of the two location-specific measures (PAI and BilNum) and the broader economic policy uncertainty index.

Although heightened economic uncertainty is a prevalent characteristic over the last decade, policy uncertainty shocks could also arise from partisan conflicts. Azzimonti (2017) defines partisan conflicts as the political disagreement between policy makers (either across party lines or within a party). Accordingly, the author notes that a higher degree of partisan conflicts will lead to more policy uncertainty because it negatively affects the optimal response to adverse shocks and the quality of policy reforms aimed at preventing them. In this regard, it is natural to assume that when the degree of partisan conflict is high, the firm's information environment deteriorates and the investors' demand for risky investments weakens, thereby leading to higher IPO underpricing. To test this hypothesis, we employ PolRisk4, which is the monthly level of the Partisan Conflict Index (PCI), as constructed by Azzimonti (2017). ${ }^{13}$ We also consider PolRisk5, which is the PAI index multiplied by the PCI, in order to incorporate the overlapping state and country-wide effects of the PAI measure and the PCI measure, respectively.

Table 8 presents the results of these four alternative policy risk measures on IPO returns. The evidence is consistent with the baseline results. All five measures are positive and significant in predicting variation on IPO underpricing, providing further support to the idea that policy risk is priced in the IPO market.

\subsection{Industry and State Fixed Effects}

Finally, we evaluate the robustness of our results by considering their sensitivity to various industry specifications. To do so, in Table 9 we repeat the baseline regression using alternative definitions of industry fixed effects (i.e., Fama French 17 and Fama-French 30). Moreover, in untabulated results, we selectively

\footnotetext{
12 The data for the EPU index can be accessed at http://www.policyuncertainty.com.

${ }^{13}$ The data for the PCI is obtained from the Real-time Data Research Center of the Federal Reserve Bank of Philadelphia (https://www.philadelphiafed.org/research-and-data/real-time-center/partisan-conflict-index).
} 
drop industries from our main results in order to assess the possibility that our results are driven by one or more industries. After re-estimating the basic equation and sequentially dropping each industry from the regression, our inferences remain unaltered. In the last two columns of Panel A (Table 9), we compare our results by excluding the industry- and state- fixed effects. We obtained similar evidence across all specifications, which indicates that the PAI effect on underpricing is not (at least significantly) influenced by unobservable industry- or state-specific factors.

\subsubsection{Influential States}

As a last robustness check, we attempt to assure that our results are not driven by influential states. Given that the 15 (the first tercile) most active states based on IPO volume constitute more than one half of our IPO sample (see Panel D of Table 1), it is possible that our main inferences are driven by a dominant state. By removing each of these states (one at a time) from the sample, we find that the results are qualitatively the same. For brevity, in Panel B of Table 9 we report only the results for three states with the high and the lowest PAI, respectively. We also repeat the same process for the states with the lowest number of IPOs. In unreported tests we find that our results remain robust (they actually become stronger) when using these subsamples.

\section{Post-IPO Outcomes}

\subsection{PAI Effect on Secondary Market Volatility}

Our central hypothesis is that political proximity proxies for the ex-ante policy-related uncertainty about the IPO's valuation. In line with this intuition, we find that political proximity is associated with higher underpricing. This finding is also consistent with a number of theories predicting that underpricing represents an attempt of the investment bankers and issuers to compensate investors for the greater costs of becoming informed (Rock, 1986; Beatty and Ritter, 1986), and as such, it constitutes an efficient response to the complexity of the valuation problem (Ritter, 1984; Welch, 1992).

An interesting aspect of this process, though, is that it enables issuers to mitigate the information asymmetry problem about the markets' aggregate demand for the firms' shares. As Lowry et al. (2010) note, the initiation of trading facilitates the incorporation of all market participants' information into the price and hence helps issuers and underwriters to more precisely estimate the clearing price. This mechanism highlights underwriters' difficulty in valuing companies characterized by high uncertainty; yet, in our context, it does not necessarily result in the elimination of the investor's policy-related adverse selection costs. One reason for this is that in order to minimize the money left on the table, corporate insiders may not accurately reveal their superior (private) information on how future government actions may affect the prospects of their firm, especially in areas exposed to greater policy risk. Another non-mutually exclusive explanation is that the time of the IPO immediate aftermarket prices are not fully informative because both 
investors and firm are not particularly knowledgeable about the nature, timing, and impact of future government actions.

Based on this reasoning, we anticipate that as long as political proximity is associated with possible future policy changes, it will adversely affect the precision of the price-setting process beyond the firsttrading day (Yung et al., 2008). To test this conjecture we explore the extent to which the PAI effect is associated with the persistence in the volatility of secondary stock returns. ${ }^{14}$

Panel A of Table 10 demonstrates that both the total return volatility and idiosyncratic volatility is higher for firms with greater political proximity. The differences between the low and high PAI regimes are significant up to 504 days ( 2 years), which is consistent with the notion that investors indeed need some time to observe the post-IPO effect of policy changes on firms. Also, it is interesting to note that the exposure to greater idiosyncratic volatility in the post-IPO period is accordance with the idea that the returns of high PAI firms reflect greater private information. Nonetheless, to investigate more rigorously the link between PAI and post-IPO return dispersion we repeat the baseline regression with the post-IPO volatility measures as the dependent variable instead of underpricing. The results in Panel B reveal a similar PAI affect after controlling for other potential determinants; however, in this multivariate setting PAI, does not seem be reliably associated with greater uncertainty about the price of the IPO stock after the first year.

\subsection{PAI Effect on Real Investment Decisions}

The analysis so far, demonstrates that as any form of uncertainty, uncertainty emanating from greater political proximity increases the risk of holding financial claims in firms' assets. Nevertheless, besides the well-documented financial effects, extensive prior evidence suggests that policy uncertainty has also real investment implications (see, for instance, Gulen and Ion, 2016; Çolak et al., 2017; Jen, 2017). Particularly, the higher discount rate associated with policy uncertainty reduces the net present value of investment projects, inducing firms to underinvest. Another layer of uncertainty, however, is added in the presence of investment irreversibility. In this case two scenarios are possible. In the anticipation of possible negative shocks, firms will delay investment in order to limit the exposure to downside risk. However, even if positive policy changes are about to take place, firms have still incentive to delay an investment, since the expected policy outcome could heterogeneously affect the attractiveness of different investment opportunities, thereby distorting the allocation of spending across alternative investment opportunities (Julio and Yook, 2012).

Therefore, either due to higher discount rate or investment irreversibility, firms located in areas with high PAI areas may find it optimal to reduce investment expenditures until the associated uncertainty is

\footnotetext{
${ }^{14}$ There are important considerations in selecting the appropriate return horizon. Particularly, the relevance of the entrepreneur's ex ante private information or the uncertainty about the government's future actions - the relevant imperfections in our setting - is probably limited at very long horizons. As a compromise, we present our results over 1-month, 3-month, 6-month, 9-month, 12months, 24-months, and 36-months. Given that new elected politicians usually reveal their intentions in the first months of their tenure and that PAI changes every two years, these periods are sufficiently long to allow for a significant amount of policy-related information to enter into the market price.
} 
resolved. We investigate the validity of this conclusion by focusing on the nature of the relationship between PAI and accounting-based investment measures at the IPO year. To do so, we employ the baseline model (column 2 of Table 11) expect with capital expenditures (CAPEX) and R\&D expenditures as the dependent variable instead of underpricing. As shown in Table 11, the coefficient of PAI is negative and significant across all specifications. This result reinforces our main hypothesis that firms located in areas of the political map that are tightly related with the President face higher uncertainty. ${ }^{15}$

\subsection{Long-Term Implications of PAI}

Our final test is concerned with the long-term implications of policy risk on IPOs. Previously we found that PAI undermines the ability of IPO issuers to raise capital, distorts the post-IPO information environment, and disrupts the firm's regularly planned investment activities. Although our analysis and the very nature of the PAI measure are suggestive of an influence that does not exceed the period of two years, it should be noted that the cash raised through an IPO can be a critical asset for a strategy of growth, and as such, it can have an enduring effect on the firms' ability to grow and capitalize future investment opportunities. Thus, we cannot rule out the possibility that PAI adversely affects the ability of a firm to operate as independent organization, i.e., to be acquired, if it faces financial problems. Similarly, one can argue that political proximity can have even more severe long-term implications if it impedes the firms' ability to meet listing exchange requirements or increases the chances of liquidation. ${ }^{16}$

To test this conjecture, we investigate whether PAI affects the incidence of delisting, that is, the survivability of IPO issuers, which is arguably the ultimate performance measure (Welbourne and Andrews, 1996; Audretsch and Lehmann, 2005). Following the convention in the literature, we assess the survivability of IPO issuers by using survival and hazard functions (Jain and Kini, 2000; Alhadab et al., 2014; Gounopoulos and Pham, 2017). To do so, we initially perform the Cox (1972) proportional hazard analysis as well as the Accelerated Failure Time (AFT) method. The selection of the Cox and AFT models over ordinary least squares (OLS) and binary dependent models is justified by the fact that IPO data are right censored, as many firms that went public are still trading (Demers and Joos, 2007). Additionally, they allow us to take into account the length of time that a company survives. ${ }^{17}$ In the Cox model, the dependent variable is failure risk and takes the value of 1 if the firm is delisted within five years after its IPO, while in the AFT model the dependent variable is the natural logarithm of the survival time which is measured in months.

Table 12 reports the results of the survival analysis. Column (1) assesses the impact of PAI using the Cox model and documents a strong and significant positive coefficient on Political Alignment. Particularly, it

\footnotetext{
${ }^{15}$ Our sample reduces because R\&D and CAPEX are available for only 1,183 firms.

${ }^{16}$ Delisting due to mergers and acquisitions (M\&A) does not necessarily represent failure because a firm may become a target due its unique competitive advantages. Given this ambiguity, we also classified as M\&A related delistings in the failed-IPO sample only if the targets were considered as low-quality firms in the year prior to their acquisition (Fama and French, 2004). This approach did not alter our inferences about the relationship between PAI and IPO survival.

${ }^{17}$ It should be noted that the time horizon that we examine the survivorship of each firm after its issuance is five years. Therefore, our sample-period spans from 2000 to 2012.
} 
shows that a unit increase of the PAI score (i.e., a shift on the political map from an area completely opposed to the president to being completely aligned) increases the failure risk by $52 \%$. Column (2) assesses the impact of PAI using the AFT method and suggests a shorter time to survive in the periods following the offering for firms operating in states with high PAI. Specifically, the coefficient on PAI is -0.45 , which suggests that a unit increase in the PAI score causes the survival time of the average firm to decrease by $36.23 \%\left[=\exp (-0.45)^{*} 1-1\right]$. In turn, this equates to a reduction in the survival time from 90.82 months $(7.87$ years) to 57.91 months (4.82 years). In short, we confirm our prediction that IPOs originating from a state that is characterized by high policy risk face a higher probability of failure.

\section{Conclusion}

This paper documents that proximity to political power tends to be positively associated with underpricing. Since politicians from areas offering high political alignment with the Presidential party are better positioned to influence the political agenda and lead legislative initiatives, we view political proximity as a major source of policy risk. We also examine the role of political connections established either through financial contributions to PACs or lobbying activities, and find that these strategies act as effective tools for hedging policy risk. Politically sensitive industries amplify the impact of policy risk, whereas the strength of the PAI-underpricing link is weakened in states of high economic freedom. The relationship between PAI and IPO first-day returns is not uniform across firms. Rather, it depends on the type of business model, maturity, and the degree of agency conflicts. The results are robust to various specifications and alternative measures of policy risk. Finally, the influence of PAI extends to the post-IPO market, discourages corporate investments, and reduces the survivability of the IPO issuers.

Arguably, the IPO market is considered as a critical economic and financial asset. However, our results suggest that one important way in which politics influence the viability of the IPO market is through the channel of local political proximity. The effects of local politics are especially relevant in the light of the recent financial crisis recession, and because traditionally they represent a major arena of interactions between small businesses and politicians. Therefore, our results may be useful to policymakers interested on the impact of uncertainty surrounding their decisions and to investors who try to take advantage of strategies based on political geography elements. 


\begin{tabular}{|c|c|}
\hline Underpricing & $\begin{array}{l}\text { The difference between the first secondary market closing price available in CRSP and IPO offer price, divided by IPO } \\
\text { offer price. }\end{array}$ \\
\hline \multicolumn{2}{|r|}{ Panel B: IPO Characteristics } \\
\hline Firm age & $\begin{array}{l}\text { The number of years elapsed since firm's foundation to IPO date, using foundation dates from Thomson Financial } \\
\text { database as well as from the Field-Ritter dataset. The variable is transformed into the regressions by adding } 1 \text { and taking } \\
\text { the natural logarithm. }\end{array}$ \\
\hline VC & Dummy variable set to 1 for venture capital-backed firms, and 0 otherwise. \\
\hline Proceeds & The natural logarithm of gross proceeds raised by the IPO estimated as shared offered times the offer price. \\
\hline Overhang & The ratio of shares retained by the pre-IPO shareholders over shares issued in the offering. \\
\hline Underwriter & $\begin{array}{l}\text { Dummy variable set to } 1 \text { for most prestigious underwriters, } 0 \text { otherwise. Most reputable underwriters are those with a } \\
\text { ranking score of } 9.0 \text { or above based on Jay Ritter's underwriter (prestige) rankings. }\end{array}$ \\
\hline Internet & $\begin{array}{l}\text { Dummy variable set to } 1 \text { for IPOs of Internet firms, and } 0 \text { otherwise. Internet firms are classified those with business } \\
\text { description containing any of the words "Internet", "Online", eBusiness", "eCommerce", and/or "Website". }\end{array}$ \\
\hline Technology firm & $\begin{array}{l}\text { Dummy variable: one for IPO firms with SIC codes } 3571,3572,3575,3577,3578 \text { (computer hardware), 3661, } 3663 \text {, } \\
3669 \text { (communications equipment), 3671, 3672, 3674, 3675, 3677, 3678, 3679 (electronics), } 3812 \text { (navigation } \\
\text { equipment), 3823, 3825, 3826, 3827, 3829 (measuring and controlling devices), 3841, } 3845 \text { (medical instruments), } \\
4812,4813 \text { (telephone equipment), } 4899 \text { (communications services), and 7371, 7372, 7373, 7374, 7375, 7378, and } 7379 \\
\text { (software). }\end{array}$ \\
\hline Nasdaq & Dummy variable set to 1 for NASDAQ-listed IPOs, and 0 otherwise. \\
\hline $\mathrm{R} \& \mathrm{D}$ & $R \& D$ is the ratio of total $R \& D$ expense to total sales in the fiscal year prior to the IPO \\
\hline Leverage & The ratio of total liabilities over total assets in the fiscal year prior to IPO. \\
\hline EPS & Dummy variable set to 1 for positive earnings per share in the fiscal year prior to IPO, and 0 otherwise. \\
\hline CAPEX & $R \& D$ is the ratio of total $R \& D$ expense to total assets in the IPO year. \\
\hline $\mathrm{R} \& \mathrm{D}$ & CAPEX is the ratio of total capital expenditures to total assets in the IPO year. \\
\hline
\end{tabular}

Panel C: State-Level Characteristics

\begin{tabular}{|c|c|}
\hline \multicolumn{2}{|r|}{ The state annual unemployment rate from the Federal Reserve Economic Data (FRED). } \\
\hline $\begin{array}{l}\text { Real GDP Growth } \\
\text { Rate }\end{array}$ & The annual state GDP growth rate using state GDP (in 2009 dollars) from the Federal Reserve Economic Data (FRED). \\
\hline Personal Income & The natural logarithm of the annual state personal income from the Bureau of Economic Analysis (BEA). \\
\hline \multicolumn{2}{|r|}{ Pane D: Political Variables } \\
\hline PAI & $\begin{array}{l}\text { The Political Alignment Index developed by Kim et al. }(2012) \text { is used as the main proxy for policy risk: PAI }= \\
(1 / 4) * \text { Senators }+(1 / 4) * \text { Representatives }+(1 / 4) * \text { Governor }+(1 / 4) *[(1 / 2) * \text { State Senators }+(1 / 2) * \text { State Representatives }]\end{array}$ \\
\hline
\end{tabular}

ModifiedPAI1 The first variant of PAI: ModifiedPAI1 $=(1 / 3) *$ Senators $+(1 / 3) *$ Representatives $+(1 / 3) *$ Governor

ModifiedPAI2 The second variant of PAI: ModifiedPAI2 $=(1 / 2) *$ Senators $+(1 / 2) *$ Representatives

$\triangle \mathrm{PAI} \quad$ The annual change in PAI.

Regional PAI The third variant of PAI: It is computed after averaging the PAI values across all states in a particular geographic region (Northeast, South, Midwest, and West). Geographic Regions are defined in note 6.

BilNum

The natural logarithm of the number of bills introduced in Congress by politicians from a given state, where the bill information is collected from E. Scott Adler and John Wilkerson, Congressional Bills Project (1984-2012).

Legislative Activity It is the number of bills introduced over the past 4 months in the political district where the firm's headquarters is Index located.

Midterm Election A year dummy that takes 1 if the year is in the second two-year of a four-year presidential term, and zero otherwise.

PolicyRisk1 It is the BilNum.

PolicyRisk2 It is the PAI index multiplied by the monthly policy uncertainty index of Baker et al. (2016).

PolicyRisk3 It is the Bills multiplied by the monthly policy uncertainty index of Baker et al. (2016)

PolicyRisk4 It is the partisan conflict index of Azzimonti (2017).

PolicyRisk5 The PAI index multiplied by the partisan conflict index of Azzimonti (2017).

PMC Dummy variable set to 1 for IPOs with lobbying and/or PAC contributions, and 0 otherwise.

Pane E: IPO Survival

Failure

Dummy variable set to 1 if the firm is delisted within five years after its IPO, and 0 otherwise.

Survival Time

The natural logarithm of the time to delist (survival time) which is measured in months. 


\section{References}

Akey, P. 2015. Valuing Changes in Political Networks: Evidence from Campaign Contributions to Close Congressional Elections. The Review of Financial Studies 28(11), 3188-3222.

Alhadab, M., Clacher, I., and Keasey, K. 2014. Real and Accrual Earnings Management and IPO Failure Risk. Accounting and Business Research 45(1), 55-92.

Amore, M., \& Minichilli, A. (2018). Local Political Uncertainty, Family Control, and Investment Behavior. Journal of Financial and Quantitative Analysis, 1-24.

Azzimonti, M. 2018. Partisan Conflict and Private Investment. Journal of Monetary Economics. Forthcoming.

Anderson, W., Box-Steffensmeier, and Sinclair-Chapman, V. 2003. The Keys to Legislative Success in the U.S. House of Representatives. Legislative Studies Quarterly 28(3), 357-386.

Ansolabehere, S., Figueiredo, J., and Snyder. J. 2003. Why is there so little Money in U.S. Politics? Journal of Economic Perspectives 17, 105-130.

Ansolabehere, S., and Snyder, J. 2006. Party Control of State Government and the Distribution of Public Expenditutes. Scandinavian Journal of Economics 108(4), 547-569.

Antia, M., Kim, I., and Pantzalis, C. 2013. Political Geography and Corporate Political Strategy. Journal of Corporate Finance 22, 361-374.

Audretsch, D., and Lehmann, E. 2005. Does the Knowledge Spillover Theory of Entrepreneurship Hold for Regions? Research Policy 34(8), 1191-1202.

Bajo, E., and Raimondo, C. 2017. Media Sentiment and IPO Underpricing. Journal of Corporate Finance 46, 139-153.

Baker, S.R., Bloom, N., and Davis, S.J. 2016. Measuring Economic Policy Uncertainty. The Quarterly Journal of Economics 131(4), 1593-1636.

Beatty, R., and Ritter, J. 1986. Investment Banking, Reputation, and the Underpricing of Initial Public Offerings. Journal of Financial Economics 15(1-2), 213-232.

Bedard, J., Coulombe, D., and Courteau, L. 2008. Audit Committee, Underpricing of IPOs, and Accuracy of Management Earnings Forecasts. Corporate Governance: An International Review 16, 519-535.

Belo, F., Gala, V., and J. Li, J. 2013. Government Spending, Political Cycles and the Cross Section of Stock Returns. Journal of Financial Economics 107, 305-324.

Benveniste, L., and Spindt, P. 1989. How Investment Bankers Determine the Offer Price and Allocation of New Issues. Journal of Financial Economics 24, 343-361.

Bernstein, S. 2015. Does Going Public Affect Innovation? The Journal of Finance 70(4), 1365-1403.

Black, B. and Gilson, R. 1998. Venture Capital and the Structure of Capital Markets: Banks versus Stock Markets. Journal of Financial Economics 47(3), 243-277.

Bonaime, A., Gulen, H., and Ion, M. 2018. Does Policy Uncertainty Affect Mergers and Acquisitions? Journal of Financial Economics, In Press.

Borisov, A., Ellul, A., and Sevilir, M. 2017. Access to Public Capital Markets and Employment Growth. Unpublished Working Paper. 
Boubakri, N., Guedhami, O., Mishra, D., and Saffar, W. 2012. Political Connections and the Cost of Equity Capital. Journal of Corporate Finance 18, 541-559.

Boutchkova, M., Doshi, H., Durnev, A., and Molchanov, A. 2012. Precarious Politics and Return Volatility. Review of Financial Studies 25(4), 1111-1154.

Bradley, D., Pantzalis, C., and Yuan, X. 2016. Policy Risk, Corporate Strategies, and the Cost of Debt. Journal of Corporate Finance 40(8), 254-275.

Bradley, D., and Jordan, B. 2002. Partial Adjustment to Public Information and IPO Underpricing. Journal of Financial and Quantitative Analysis 37(4), 595-616.

Brogaard, J., and Detzel, A. 2015. The Asset Pricing Implications of Government Economic Policy Uncertainty. Management Science 61(1), 3-18.

Butler, A., Fauver, L., and Spyridopoulos, I. 2017. Local Economic Consequences of Stock Market Listing. Working Paper. SSRN

Carter, R., Dark, F., Singh, A., K. 1998. Underwriter Reputation, Initial Returns, and the Long-Run Performance of IPO Stocks. The Journal of Finance 53(1), 285-311.

Carter, R., and Manaster, S. 1990. Initial Public Offerings and Underwriter Reputation. The Journal of Finance 45(4), 1045-1067.

Certo, T., Daily, C., Cannella, J., and Dalton, D. 2003. Giving Money to Get Money: How CEO Stock Options and CEO Equity Enhance IPO Valuations. The Academy of Management Journal 46(5), 643-653.

Chaplinksy, S., Hanley, K., and Moon, S. 2017. The JOBS Act and the Costs of Going Public. Journal of Accounting Research 55, 795-836.

Cohen, B., and Dean, T. 2005. Information Asymmetry and Investor Valuation of IPOs: Top Management Tea Legitimacy as a Capital Market Signal. Strategic Management Journal 26(7), 683-690.

Cohen, L., and Malloy, C. 2010. Friends in High Places. American Economic Journal: Economic Policy 6(3), 63-91.

Cohen, L., Diether, K., and Malloy, C. 2013. Legislative Stock Prices. Journal of Financial Economics 110(3), 574-595.

Çolak, G., and Gunay, H. 2011. Strategic Waiting in the IPO Markets. Journal of Corporate Finance 17 (3), 555-583.

Çolak, C., Durnev, A., and Qian, Y. 2017. Political Uncertainty and IPO Activity: Evidence from U.S. Gubernatorial Elections. Journal of Financial and Quantitative Analysis 52(6), 2523-2564.

Cooper, M., H. Gulen, H., and Obtchinnikov, A. 2010. Corporate Political Contributions and Stock Returns. Journal of Finance 65 (2), 687-724.

Correia, M. 2014. Political Connections and SEC Enforcement. Journal of Accounting and Economics 57, 241-262.

Cox, D. 1972. Regression Models and Life-Tables. Journal of Royal Statistical Society (Series B) 34(2), 187220.

Cox, G., and McCubbins, M. 1986. Electoral Politics as a Redistributive Game. The Journal of Politics 48 (2), 370-389. 
Croci, E. Pantzalis, C., Park, C., and Petmezas, D. 2017. The Role of Corporate Political Strategies in M\&As. Journal of Corporate Finance 43, 260-287.

Demers, E., and Joos, P. 2007. IPO Failure Risk. Journal of Accounting Research 45(2), 333-371.

Do, Q., Lee, Y., and Nguyen, B., 2005. Political Connections and Firm Value: Evidence from Close Gubernatorial Elections. Unpublished Working Paper.

Dolvin, S., and Jordan, B. 2008. Underpricing, Overhang, and the Cost of Going Public to Preexisting Shareholders. Journal of Business and Finance Accounting 35(3-4), 434-453.

Doidge, D., Karolyi, A., and Stulz, R. 2013 The U.S. Left Behind? Financial Globalization and the Rise of IPOs Outside the U.S.. Journal of Financial Economics 110(3), 546-573.

Downs, A. 1957. An Economic Theory of Democracy, Harper and Row, New-York.

Duchin, R., and Sosyura, D. 2012. The Politics of Government Investment. Journal of Financial Economics 106 (1), 24-48.

Durnev, A. 2012. The Real Effects of Political Uncertainty: Elections and Investment Sensitivity to Stock Prices. Unpublished Working Paper.

Faccio, M. 2006. Politically Connected firms. American Economic Review 96, 369- 386

Faccio, M., Masulis, R., and McConnell, J. 2006. Political Connections and Corporate Bailouts. Journal of Finance 61, 2597-2635.

Faccio, M., and Parsley, D. 2009. Sudden deaths: Taking Stock of Geographic Ties. Journal of Financial and Quantitative Analysis 44, 683-718.

Fama, E., and French, K. 2004. The Capital Asset Pricing Model: Theory and Evidence. Journal of Economic Perspectives 18(3), 25-46.

Ferguson, M., and Witte, H. 2006. Congress and the Stock Market. University of Cincinnati and University of Missouri at Columbia. Unpublished Working Paper.

Filatotchev, I., and Bishop, K. 2002. Board Composition, Share Ownership, and 'Underpricing' of U.K. IPO Firms. Strategic Management Journal 23, 941-955.

Fowler, J.H., 2006. Elections and markets: the effect of partisanship, policy risk, and electoral margins on the economy. Journal of Politics 68, 89-103.

Francis, B., Hasan, I., and Sun, X. 2009. Political Connections and the Process of Going public: Evidence from China. Journal of International Money and Finance 28, 696-719.

Francis, B. Hasan, I., and Zhu, Y. 2014. Political Uncertainty and Bank Loan Contracting. Journal of Empirical Finance 29(3), 281-286.

Füss, R., Bechtel, M. 2008. When Investors Enjoy Less Policy Risk: Divided Government, Economic Policy Change and Stock Market Volatility in Germany, 1970-2005. Swiss Political Science Review 14, 287-314.

Gao, P., and Qi, X. 2013. Political Uncertainty and Public Financing Costs: Evidence from U.S. Municipal Bond Markets. Working Paper, City University of Hong Kong.

Goodell, W., J. and Vähämaa, S. 2013. US Presidential Elections and Implied Volatility: the Role of Political Uncertainty. Journal of Banking and Finance, 37(3), pp. 1108-1117.

Goldman E, Rocholl, J., and So, J. 2009. Do Politically Connected Boards Affect Firm Value? Review of Financial Studies 22, 2331-2360. 
Goldman, E., So, J., and Rocholl, J. 2013. Politically Connected Boards of Directors and the Allocation of Procurement Contracts. European Financial Review 17 (5), 1617-1648.

Gounopoulos, D., Kallias, K., Kallias, A., and Tzeremes, P., 2017. Political Money Contributions of US IPO Firms. Journal of Corporate Finance 43, 19-38.

Gounopoulos, D., and Pham, H. 2018. Specialist CEOs and IPO Survival. Journal of Corporate Finance 48, 217-243.

Gross, C., Konigsgruber, R., Pantzalis, C. and Perotti, P. 2016. The Financial Reporting Consequences of Proximity to Political Power. Journal of Accounting Public Policy 35, 609-634.

Gulen, H., and Ion, M. 2016. Policy Uncertainty and Corporate Investment. Review of Financial Studies 29(3), 523-564.

Hadley, B. 2016. Executive Compensation and Political Sensitivity: Evidence from Government Contractors. Journal of Corporate Finance. Forthcoming.

Heckman, J. 1979. Sample Selection Bias as a Specification Error. Econometrica 47(1), 153-161.

Heese, J. 2015. Government Preferences and SEC Enforcement Unpublished Manuscript. Harvard Business School.

Higgins, M., and Gulati, R. 2006. Stacking the Deck: The Effects of Top Management Backgrounds on Investor Decisions. Strategic Management Journal 27, 1-25.

Hill, M., Kelly, W., Lockhart, G., B., and Van Ness, R. 2013. Determinants and Effects of Corporate Lobbying. Financial Management 42, 931-957.

Houston, J. F., Jiang, L., Lin, C., and Ma, Y. 2014. Political Connections and the Cost of Bank Loans. Journal of Accounting Research, 52(1), 193-243.

Igan, D., Mishra, P., and Tressel, T. 2011. A Fistful of Dollars: Lobbying and the Financial Crisis. National Bureau of Economic Research.

Irrine, P., Pontiff, J. 2009. Idiosyncratic Return, Volatility, Cash Flows and Product Market Competition. Review of Financial Studies 22(3), 1149-1177.

Jain, B., and O. Kini, O. 2000. Does the Presence of Venture Capitalists Improve the Survival Profile of IPO Firms? Journal of Business Finance and Accounting 27(9-10), 1139-1183.

Jayachandran, S. 2006. The Jeffords Effect. Journal of Law and Economics 49(2), 397-425.

Jens, C. 2017. Political Uncertainty and Investment: Causal Evidence from U.S. Gubernatorial Elections. Journal of Financial Economics 124, 563-579.

Johnston, R. 1977. Environment, Elections and Expenditure: Analyses of Where Governments Spend. Regional Studies 11, 383-94

Johnston, R. 1978. Congressional Committees and Department Spending. Transactions of the Institute of British Geographers 4, 372-384.

Joo, J., Kim, D., and Park, J. 2016. Local Political Support and Stock Returns. Unpublished Working Paper.

Julio, B., and Yook, Y. 2012. Political Uncertainty and Corporate Investment Cycles. The Journal of Finance 67(1), 45-83.

Julio, B., and Yook, Y. 2016. Policy Uncertainty, Irrepressibility, and Cross-Border Flows of Capital. Journal of International Economics 103, 13-26. 
Kelly, B., Pastor, L., and Veronesi, P. 2016. The Price of Political Uncertainty: Theory and Evidence from the Option Market. The Journal of Finance 71(5), 2417-2480.

Kenney, M., Patton, D., and Ritter, J. 2012. Post-IPO Employment and Revenue Growth for U.S. IPOs, June 1996-2010. Kansas City, MO: Ewing Marion Kauffman Foundation.

Kim, C., Pantzalis, C., and Park, C. 2012. Political Geography and Stock Returns: The Value and Risk Implications of Proximity to Political Power. Journal of Financial Economics 106(1), 196-228.

Kim, C., and Zhang, L. 2016. Corporate Political Connections and Tax Aggressiveness. Contemporary Accounting Research 33(1), 78-114.

Kostovetsky, L. 2015. Political Capital and Moral Hazard. Journal of Financial Economics 116(1), 144-159.

Kramer, G. 1966. A Decision-Theoretic Analysis of a Problem in Political Campaigning. In: Bernd, J.L. (Ed.), Mathematical Applications in Political Science, vol. 11, Southern Methodist University, Dallas, 137160.

Krishnan, C., Ivanov, V., Masulis, R., and Singh, A. 2011. Venture Capital Reputation, Post-IPO Performance, and Corporate Governance. Journal of Financial and Quantitative Analysis 46(5), 1295-1333.

Kroszner, R., and Stratmann, T. 1998. Interest-Group Competition and the Organization of Congress: Theory and Evidence from Financial Services' Political Action Committees. American Economic Review 88(5), 1163-1187.

Krutz, G., 2005. Issues and institutions: winnowing in the U.S. Congress. American Journal of Political Science 49, 313-326

Langbein, L. and Lotwis, M. 1990. The Political Efficacy of Lobbying and Money: Gun Control in the U. S. House, 1986. Legislative Studies Quarterly 15(3), 413-440.

Leone, A., Rock, S., and Willenborg, M. 2007. Disclosure of Intended Use of Proceeds and Underpricing in Initial Public Offerings. Journal of Accounting Research 45(1), 111-153.

Lee, P. M., and Wahal, S. 2004. Grandstanding, Certification and the Underpricing of Venture Capital Backed IPOs. Journal of Financial Economics 73(2), 375-407.

Li, H., Meng, L., Wang, Q., and Zhou, L. 2008. Political Connections, Financing and Firm Performance: Evidence from Chinese Private Firms. Journal of Development Economics 87(2), 283-299.

Li, J., and Born, J. 2006. Presidential Election Uncertainty and Common Stock Returns in the United States. The Journal of Financial Research 29(4), 609-622.

Ljungqvist, A., 2007. IPO Underpricing: A Survey. Handbook in Corporate Finance: Empirical Corporate Finance. B. Espen Eckbo, ed.

Loughran, T. 1993. NYSE vs NASDAQ Returns: Market Microstructure or the Poor Performance of Initial Public Offerings? Journal of Financial Economics 33(2), 241-260.

Loughran, T., and Ritter, J. 2004. Why has IPO Underpricing Changed over Time? Financial Management 33(3), 5-37.

Lowry, M., and Murphy, K. 2007. Executive Stock Options and IPO Underpricing. Journal of Financial Economics 85, 39-65.

Lowry, M., Michaely, R., and Volkova, G. 2017. Initial Public Offerings: A Synthesis of the Literature and Directions for Future Research. Forthcoming Foundations and Trends in Finance. 
Lowry, M., Officer, M., and Schwert, W. 2010. The Variability of IPO Initial Returns. Journal of Finance $65(2), 425-465$.

Malkiel, B. 1979. The Capital Formation Problem in the United States. Journal of Finance 34, 291-306.

Mayhew, D. 1974. Congress: The Electoral Connection. Yale University Press, New Haven.

Mouw, C., and Mackuen, M. 1992. The Strategic Agenda in Legislative Politics. American Political Science Review 86(1), 87-105.

Michaely, R., and Shaw, W. 1994. The Pricing of Initial Public Offerings: Tests of Adverse-Selection and Signaling Theories. Review of Financial Studies 7(2), 279-319.

Nielsson, U., and Wójcik, D. 2016. Proximity and IPO Underpricing. Journal of Corporate Finance 38, 92105.

O'Brien C., and Tan, H. 2015. Geographic Proximity and Analyst Coverage Decisions: Evidence from IPOs. Journal of Accounting and Economics 59(1), pp. 41-59.

Pantzalis, C., and Park, J., C. 2014. Too close for comfort? Geographic Propinquity to Political Power and Stock Returns. Journal of Banking and Finance 48, 57-78.

Pantzalis, C., Stangeland, D., Turtle, H. 2000. Political Elections and the Resolution of Uncertainty: The International Evidence. Journal of Banking and Finance 24(10), 1575-1604.

Pasquariello, P., and Zafeiridou, C., 2014. Political Uncertainty and Financial Market Quality. Working Paper, SSRN

Pastor, L., and Veronesi, P. 2012 Uncertainty About Government Policy and Stock Prices. The Journal of Finance 67(4), 1219-1264.

Pastor, L., and Veronesi, P. 2013. Political Uncertainty and Risk Premia. Journal of Financial Economics 110(3), 520-545.

Ritter, J. 1984. The 'Hot Issue' Market of 1980. Journal of Business 57, 215-240.

Ritter, J., and Welch, I. 2002. A Review of IPO Activities, Pricing and Allocation, Journal of Finance 57, 1795-1828.

Roberts, B. 1990. Political Institutions, Policy Expectations, and the 1980 Election: A Financial Market Perspective. American Journal of Political Science 34(2), 289-310.

Rock K., 1986. Why New Issues Are Underpriced, Journal of Financial Economics 15, 187-212.

Santa-Clara, P., and Volkanov, R. 2003. The Presidential Puzzle: Political Cycles and the Stock Market. The Journal of Finance 58(5), 1841-1872.

Schenone, C. 2005. The Effect of Banking Relationships on the Firm's IPO Underpricing. Journal of Finance 59(6), 2903-2958.

Skaife, H., Veenmanm, D., and Werner, T. 2013. Corporate Lobbying and CEO Pay, Working Paper University of Texas, 1-46.

Shleifer, A., and Vishny, R. 1994. Politicians and Firms. Quarterly Journal of Economics 109, 995-1025.

Shleifer, A., and Vishny, R. 1998. The Grabbing Hand: Government Pathologies and Their Cures. Harvard University Press, Cambridge MA. 
Tahoun, A. 2014. The Role of Stock Ownership by US Members of Congress on the Market for Political Favors. Journal of Financial Economics 111(1), 86-110.

Tullock, A. 1976. The Vote Motive London: Institute of Economic Affairs.

Waisman, M., Pengfei, Y. and Yun, Z. 2015. The Effect of Political Uncertainty on the Cost of Corporate Debt. Journal of Financial Stability 16(3), 106-117.

Welbourne, T., and Andrews, A. 1996. Predicting the Performance of Initial Public Offerings: Should Human Resource Management Be in the Equation? The Academy of Management Journal 39(4), 891-919.

Welch, I. 1992. Sequential Sales, Learning, and Cascades. Journal of Finance 47(2), 695-732.

Wellman, L. 2017. Mitigating Political Uncertainty. Review of Accounting Studies 22, 217-250.

Wu, W., Wu, C., Zhou, C., and Wu, J. 2012. Political Connections, Tax Benefits and Firm Performance: Evidence from China. Journal of Accounting and Public Policy 31(3), 277-300.

Yang, Z. 2013. Do Political Connections Add Value to Audit Firms? Evidence from IPO Audits in China. Contemporary Accounting Research 30(3), 891-921.

Yung, C., Çolak, G., and Wang, W. 2008. Cycles in the IPO Market. Journal of Financial Economics 89(1), 192-208. 
Table 1: Distribution Statistics

This Table presents distributional statistics for a sample of 1,639 U.S. IPOs from 1 January 2000 to 31 December 2016. In Panel A the IPOs are described by issue-year, whereas in Panel B the IPOs are distributed by industry. Finally, Panel C reports state-level distribution characteristics. All variables are defined in Appendix A. IPO deals are retrieved from the Securities Data Company (SDC) database.

\begin{tabular}{|c|c|c|c|c|c|c|c|c|}
\hline \multicolumn{9}{|c|}{ Panel A: Yearly Distribution of IPO Activity, Underpricing and Political Alignment Index (PAI) } \\
\hline Year & President & Senate & \multicolumn{2}{|c|}{$\begin{array}{c}\text { House of } \\
\text { Representatives }\end{array}$} & N. & $\%$ & Underpricing & PAI \\
\hline 2000 & Clinton (D) & $\mathrm{R}$ & \multicolumn{2}{|c|}{$\mathrm{R}$} & 260 & 15.86 & $56.48 \%$ & 0.63 \\
\hline 2001 & Bush (R) & $\mathrm{D}$ & \multicolumn{2}{|l|}{$\mathrm{R}$} & 58 & 3.54 & $20.83 \%$ & 0.44 \\
\hline 2002 & Bush (R) & $\mathrm{R}$ & \multicolumn{2}{|l|}{$\mathrm{R}$} & 48 & 2.93 & $9.08 \%$ & 0.50 \\
\hline 2003 & Bush (R) & $\mathrm{R}$ & \multicolumn{2}{|l|}{$\mathrm{R}$} & 47 & 2.87 & $12.72 \%$ & 0.47 \\
\hline 2004 & Bush (R) & $\mathrm{R}$ & \multicolumn{2}{|l|}{$\mathrm{R}$} & 125 & 7.63 & $11.41 \%$ & 0.47 \\
\hline 2005 & Bush (R) & $\mathrm{R}$ & \multicolumn{2}{|l|}{$\mathrm{R}$} & 114 & 6.96 & $9.31 \%$ & 0.50 \\
\hline 2006 & Bush (R) & $\mathrm{R}$ & \multicolumn{2}{|l|}{$\mathrm{R}$} & 124 & 7.57 & $11.27 \%$ & 0.52 \\
\hline 2007 & Bush (R) & $\mathrm{D}$ & \multicolumn{2}{|l|}{$\mathrm{D}$} & 111 & 6.77 & $12.82 \%$ & 0.38 \\
\hline 2008 & Bush (R) & $\mathrm{D}$ & \multicolumn{2}{|l|}{$\mathrm{D}$} & 17 & 1.04 & $6.95 \%$ & 0.44 \\
\hline 2009 & Obama (D) & $\mathrm{D}$ & \multicolumn{2}{|l|}{$\mathrm{D}$} & 37 & 2.26 & $14.18 \%$ & 0.58 \\
\hline 2010 & Obama (D) & $\mathrm{D}$ & \multicolumn{2}{|l|}{$\mathrm{D}$} & 72 & 4.39 & $7.02 \%$ & 0.60 \\
\hline 2011 & Obama (D) & $\mathrm{D}$ & \multicolumn{2}{|l|}{$\mathrm{R}$} & 68 & 4.15 & $14.11 \%$ & 0.51 \\
\hline 2012 & Obama (D) & $\mathrm{D}$ & \multicolumn{2}{|l|}{$\mathrm{R}$} & 80 & 4.88 & $16.95 \%$ & 0.52 \\
\hline 2013 & Obama (D) & $\mathrm{D}$ & \multicolumn{2}{|l|}{$\mathrm{R}$} & 136 & 8.30 & $20.82 \%$ & 0.56 \\
\hline 2014 & Obama (D) & $\mathrm{D}$ & \multicolumn{2}{|l|}{$\mathrm{R}$} & 171 & 10.43 & $14.98 \%$ & 0.61 \\
\hline 2015 & Obama (D) & $\mathrm{R}$ & \multicolumn{2}{|l|}{$\mathrm{R}$} & 103 & 6.28 & $16.55 \%$ & 0.56 \\
\hline 2016 & Obama (D) & $\mathrm{R}$ & \multicolumn{2}{|c|}{$\mathrm{R}$} & 68 & 4.15 & $10.11 \%$ & 0.48 \\
\hline \multicolumn{9}{|c|}{ Panel B: Distribution of IPO Activity, Underpricing and Political Alignment Index (PAI) by Industry } \\
\hline \multicolumn{3}{|c|}{ Industry } & \multicolumn{4}{|c|}{ SIC $\quad$ N. Percentage } & Underpricing & PAI \\
\hline \multicolumn{3}{|c|}{ Oil and Gas } & (13) & 62 & \multicolumn{2}{|c|}{$3.78 \%$} & $4.79 \%$ & 0.47 \\
\hline \multicolumn{3}{|c|}{ Food Products } & (20) & 18 & \multicolumn{2}{|c|}{$1.10 \%$} & $10.45 \%$ & 0.56 \\
\hline \multicolumn{3}{|c|}{ Chemical Products } & (28) & 330 & \multicolumn{2}{|c|}{$20.13 \%$} & $11.48 \%$ & 0.58 \\
\hline Manufactu & & & $(30-34)$ & 36 & & & $19.07 \%$ & 0.59 \\
\hline Computer & pment \& Serv & & $(35,73)$ & 423 & & & $36.64 \%$ & 0.52 \\
\hline Electronic & pment & & (36) & 135 & & & $39.90 \%$ & 0.57 \\
\hline Scientific & iments & & $(38)$ & 120 & & & $16.91 \%$ & 0.54 \\
\hline Transporta & \& Public Utili & & $(41,42,44-49)$ & 127 & & & $9.72 \%$ & 0.49 \\
\hline Wholesale & etail Trade & & $(50-59)$ & 144 & & & $17.37 \%$ & 0.48 \\
\hline Entertainm & Services & & $(70,78,79)$ & 26 & & & $6.99 \%$ & 0.45 \\
\hline
\end{tabular}


Table 1: Distribution Statistics (continued)

\begin{tabular}{|c|c|c|c|c|c|c|c|}
\hline & PAI & Underpricing & IPO Activity & & PAI & Underpricing & IPO Activity \\
\hline State & Mean & Mean & $\mathrm{N}$ & State & Mean & Mean & $\mathrm{N}$ \\
\hline $\mathrm{AL}$ & 0.39 & 4.91 & 2 & MS & 0.38 & 61.81 & 2 \\
\hline $\mathrm{AR}$ & 0.40 & 0.45 & 2 & MT & 0.50 & 1.50 & 2 \\
\hline $\mathrm{AZ}$ & 0.31 & 22.64 & 25 & $\mathrm{NC}$ & 0.38 & 11.85 & 42 \\
\hline CA & 0.67 & 28.08 & 475 & ND & 0.37 & 11.53 & 1 \\
\hline $\mathrm{CO}$ & 0.60 & 12.67 & 49 & $\mathrm{NE}$ & 0.34 & 21.14 & 4 \\
\hline CT & 0.64 & 16.00 & 22 & $\mathrm{NH}$ & 0.62 & 3.90 & 4 \\
\hline $\mathrm{DE}$ & 0.61 & 35.79 & 8 & NJ & 0.37 & 15.09 & 71 \\
\hline FL & 0.48 & 16.33 & 48 & NV & 0.56 & 20.97 & 9 \\
\hline GA & 0.50 & 12.76 & 42 & NY & 0.62 & 13.63 & 77 \\
\hline $\mathrm{HI}$ & 0.61 & -10.67 & 1 & $\mathrm{OH}$ & 0.54 & 12.81 & 19 \\
\hline IA & 0.44 & 0.39 & 3 & OK & 0.36 & 6.12 & 21 \\
\hline ID & 0.46 & 12.75 & 2 & OR & 0.59 & 0.26 & 4 \\
\hline IL & 0.46 & 22.66 & 64 & PA & 0.47 & 9.55 & 66 \\
\hline IN & 0.37 & 45.84 & 12 & RI & 0.61 & 6.56 & 1 \\
\hline $\mathrm{KS}$ & 0.35 & 13.14 & 6 & $\mathrm{SC}$ & 0.44 & 102.08 & 1 \\
\hline KY & 0.51 & 11.78 & 7 & $\mathrm{TN}$ & 0.32 & 5.63 & 27 \\
\hline LA & 0.33 & 7.63 & 7 & TX & 0.38 & 15.89 & 167 \\
\hline MA & 0.66 & 24.38 & 145 & UT & 0.36 & 8.92 & 13 \\
\hline MD & 0.62 & 23.36 & 34 & VA & 0.56 & 26.62 & 43 \\
\hline ME & 0.36 & -5.00 & 1 & WA & 0.53 & 36.26 & 34 \\
\hline MI & 0.42 & 8.34 & 15 & WI & 0.44 & 7.49 & 15 \\
\hline MN & 0.57 & 20.40 & 26 & WV & 0.45 & 67.30 & 1 \\
\hline MO & 0.56 & 9.13 & 16 & WY & 0.39 & -1.88 & 3 \\
\hline
\end{tabular}


Table 2: Administration Distribution by PAI and Underpricing

This Table shows the summary statistics of the dependent variable (underpricing) and the main independent variables of interest used in the regression analysis (PAI). Panel A and Panel B display the statistics of PAI and underpricing using the administration distribution. Panel C utilizes that values of PAI and ranks each state-year the home state of the President, Vice President and Speaker.

\begin{tabular}{|c|c|c|c|c|c|c|c|}
\hline \multicolumn{8}{|c|}{ Panel A: PAI Distribution by Administration } \\
\hline $\begin{array}{c}\text { Party } \\
\text { President }\end{array}$ & All & $\begin{array}{c}\text { Democrats } \\
\text { Clinton } \\
\end{array}$ & $\begin{array}{c}\text { Republicans } \\
\text { Bush } \\
\end{array}$ & $\begin{array}{c}\text { Democrats } \\
\text { Obama }\end{array}$ & Democrats only & Repul & icans only \\
\hline $\begin{array}{l}\text { All states } \\
\text { (mean) }\end{array}$ & 0.48 & 0.48 & 0.51 & 0.45 & 0.45 & & 0.51 \\
\hline $\begin{array}{c}\text { All } \\
\text { states(SD) }\end{array}$ & 0.30 & 0.24 & 0.27 & 0.35 & 0.33 & & 0.27 \\
\hline $\begin{array}{l}\text { Top } 10 \\
\text { (Mean) }\end{array}$ & 0.86 & 0.77 & 0.85 & 0.89 & 0.88 & & 0.85 \\
\hline $\begin{array}{l}\text { Bottom } 10 \\
\text { (Mean) }\end{array}$ & 0.15 & 0.22 & 0.21 & 0.09 & 0.10 & & 0.21 \\
\hline \multicolumn{8}{|c|}{ Panel B: Distribution of Underpricing by Administration } \\
\hline $\begin{array}{c}\text { Party } \\
\text { President }\end{array}$ & All & $\begin{array}{l}\text { Democrats } \\
\text { Clinton }\end{array}$ & $\begin{array}{l}\text { Republicans } \\
\text { Bush }\end{array}$ & $\begin{array}{l}\text { Democrats } \\
\text { Obama }\end{array}$ & Democrats only & Repul & icans only \\
\hline $\begin{array}{l}\text { All states } \\
\text { (Mean) }\end{array}$ & 20.43 & 56.48 & 11.91 & 15.14 & 25.94 & & 1.91 \\
\hline $\begin{array}{l}\text { All states } \\
\text { (SD) }\end{array}$ & 42.55 & 79.29 & 24.17 & 27.53 & 50.28 & & 4.17 \\
\hline $\begin{array}{l}\text { Top } 10 \\
\text { (Mean) }\end{array}$ & 26.31 & 59.94 & 6.84 & 18.79 & 30.94 & & 5.84 \\
\hline $\begin{array}{l}\text { Bottom } 10 \\
\text { (Mean) }\end{array}$ & 14.79 & 49.60 & 14.05 & 11.01 & 15.78 & & 4.05 \\
\hline \multicolumn{8}{|c|}{ Panel C: Ranking of the Presidents', Vice Presidents' and Speakers' Home State by PAI } \\
\hline Position & President & President & $\begin{array}{c}\text { Vice } \\
\text { President }\end{array}$ & $\begin{array}{c}\text { Vice } \\
\text { President }\end{array}$ & Speaker & Speaker & Speaker \\
\hline Name & Bush & Obama & Cheney & Biden & Hastert & Pelosi & Boehner \\
\hline $\begin{array}{c}\text { Political } \\
\text { Party }\end{array}$ & Republican & Democratic & Republican & Democratic & Republican & Democratic & Republican \\
\hline Time Period & 2001-2008 & 2009-2016 & 2001-2008 & 2009-2016 & 2001-2006 & $2007-2010$ & 2011-2016 \\
\hline State & Texas & Illinois & Wyoming & Delaware & Illinois & California & Ohio \\
\hline Ranking & 4 & 15 & 6 & 1 & 46 & 41 & 32 \\
\hline PAI & 0.87 & 0.73 & 0.81 & 0.94 & 0.24 & 0.46 & 0.19 \\
\hline
\end{tabular}


Table 3: Summary Statistics

This Table presents the descriptive statistics for a sample of 1,639 U.S. IPOs from 1 January, 2000 to 31 December, 2016. Firm fundamentals and offering characteristics are illustrated in Panel A. State characteristics are reported in panel B. Tests of differences in means between the two sub-samples of IPO firms with high and low PAI are based on t-tests. All variables are defined in Appendix A.

\begin{tabular}{lccccc}
\hline \multicolumn{5}{c}{ Panel A: Firm Fundamentals and Offering Characteristics } \\
\hline & Full Sample & (N=1,639) & High PAI & Low PAI & Difference \\
\hline Underpricing & Mean & SD & Mean & Mean & p-value \\
Firm Age & 20.43 & 42.55 & 24.06 & 16.78 & 0.0003 \\
Leverage & 14.06 & 18.81 & 13.67 & 14.46 & 0.1975 \\
Proceeds (\$ mil) & 0.37 & 0.41 & 0.39 & 0.35 & 0.0224 \\
EPS & 218.97 & 695.81 & 238.60 & 199.29 & 0.1264 \\
VC & 0.46 & 0.50 & 0.38 & 0.54 & 0.0000 \\
Underwriter & 0.52 & 0.50 & 0.57 & 0.48 & 0.0003 \\
Internet & 0.40 & 0.49 & 0.43 & 0.38 & 0.0115 \\
Technology & 0.10 & 0.30 & 0.11 & 0.09 & 0.0372 \\
Nasdaq & 0.36 & 0.48 & 0.38 & 0.33 & 0.0214 \\
\hline & 0.69 & 0.46 & 0.70 & 0.68 & 0.1873 \\
\hline Real GDP Growth Rate & 2.84 & 2.34 & 3.13 & 2.55 & 0.0000 \\
Personal Income & 27.02 & 0.91 & 27.20 & 26.85 & 0.0000 \\
Unemployment Rate & 5.95 & 1.98 & 6.40 & 5.49 & 0.0000 \\
\hline
\end{tabular}


Table 4: Effects of PAI on Underpricing

This Table displays the effects of PAI on IPO first-day returns using ordinary least square (OLS) regressions. The sample consists of initial public offerings from 2000 to 2016 in the U.S. stock market. The dependent variable is IPO first-day returns and is calculated as the percentage change from the first day closing price to offer price. PAI is the Political Alignment Index. Models (1), (2), (3), (4), and (5) include PAI, Modified PAI1, Modified PAI2, $\triangle$ PAI, and Regional PAI. Year, state and industry fixed effects are included but coefficient estimates are not reported. T-statistics are included in the parentheses, are adjusted for heteroskedasticity robust standard errors and clustered by state. ***, **, and * denote significance at the $1 \%, 5 \%$, and $10 \%$ levels, respectively. All variables are defined in Appendix A.

\begin{tabular}{|c|c|c|c|c|c|}
\hline & (1) & (2) & (3) & (4) & (5) \\
\hline PAI & $\begin{array}{c}6.60 * * * \\
(3.44)\end{array}$ & & & & \\
\hline Modified PAI1 & & $\begin{array}{c}7.13 * \\
(1.94)\end{array}$ & & & \\
\hline Modified PAI2 & & & $\begin{array}{c}8.47 * * * \\
(2.85)\end{array}$ & & \\
\hline$\triangle \mathrm{PAI}$ & & & & $\begin{array}{r}3.74 * * * \\
(2.84)\end{array}$ & \\
\hline Regional PAI & & & & & $\begin{array}{l}1.85^{*} \\
(1.79)\end{array}$ \\
\hline Firm Age & $\begin{array}{c}0.15 \\
(0.18)\end{array}$ & $\begin{array}{c}0.14 \\
(0.18)\end{array}$ & $\begin{array}{c}0.16 \\
(0.19)\end{array}$ & $\begin{array}{c}0.95 * * \\
(2.28)\end{array}$ & $\begin{array}{c}0.26 \\
(0.30)\end{array}$ \\
\hline Leverage & $\begin{array}{c}0.71 \\
(0.23)\end{array}$ & $\begin{array}{c}0.72 \\
(0.23)\end{array}$ & $\begin{array}{c}0.68 \\
(0.23)\end{array}$ & $\begin{array}{c}2.58 \\
(1.22)\end{array}$ & $\begin{array}{c}0.89 \\
(0.28)\end{array}$ \\
\hline Proceeds & $\begin{array}{l}2.61 * \\
(1.90)\end{array}$ & $\begin{array}{l}2.63^{*} \\
(1.91)\end{array}$ & $\begin{array}{l}2.65^{*} \\
(1.95)\end{array}$ & $\begin{array}{c}1.82 \\
(1.30)\end{array}$ & $\begin{array}{l}2.89 * \\
(1.87)\end{array}$ \\
\hline EPS & $\begin{array}{c}3.45 \\
(1.26)\end{array}$ & $\begin{array}{c}3.44 \\
(1.25)\end{array}$ & $\begin{array}{c}3.49 \\
(1.28)\end{array}$ & $\begin{array}{c}1.07 \\
(0.68)\end{array}$ & $\begin{array}{c}3.02 \\
(1.12)\end{array}$ \\
\hline Overhang & $\begin{array}{c}1.21 * * * \\
(8.72)\end{array}$ & $\begin{array}{c}1.21 * * * \\
(8.57)\end{array}$ & $\begin{array}{c}1.21 * * * \\
(8.96)\end{array}$ & $\begin{array}{c}0.97 * * * \\
(3.23)\end{array}$ & $\begin{array}{c}1.22 * * * \\
(8.75)\end{array}$ \\
\hline $\mathrm{VC}$ & $\begin{array}{c}14.07 * * * \\
(4.16)\end{array}$ & $\begin{array}{c}14.05^{* * *} * \\
(4.12)\end{array}$ & $\begin{array}{c}14.27 * * * \\
(4.31)\end{array}$ & $\begin{array}{c}7.41 * * * \\
(3.80)\end{array}$ & $\begin{array}{c}13.88 * * * \\
(8.75)\end{array}$ \\
\hline Underwriter & $\begin{array}{c}3.13 \\
(1.40)\end{array}$ & $\begin{array}{c}3.09 \\
(1.37)\end{array}$ & $\begin{array}{c}3.08 \\
(1.39)\end{array}$ & $\begin{array}{c}0.96 \\
(0.76)\end{array}$ & $\begin{array}{c}3.18 \\
(1.40)\end{array}$ \\
\hline Internet & $\begin{array}{c}-2.78 \\
(-0.36)\end{array}$ & $\begin{array}{c}-2.79 \\
(-0.36)\end{array}$ & $\begin{array}{c}-2.91 \\
(-0.38)\end{array}$ & $\begin{array}{c}-1.41 \\
(-0.30)\end{array}$ & $\begin{array}{c}-2.79 \\
(-0.36)\end{array}$ \\
\hline Technology & $\begin{array}{l}6.26^{*} \\
(1.89)\end{array}$ & $\begin{array}{l}6.28^{*} \\
(1.86)\end{array}$ & $\begin{array}{c}6.52 * * \\
(2.04)\end{array}$ & $\begin{array}{c}0.05 \\
(0.03)\end{array}$ & $\begin{array}{l}6.00 * \\
(1.90)\end{array}$ \\
\hline Nasdaq & $\begin{array}{c}3.03 \\
(0.66)\end{array}$ & $\begin{array}{c}3.05 \\
(1.37)\end{array}$ & $\begin{array}{c}3.12 \\
(0.68)\end{array}$ & $\begin{array}{c}1.67 \\
(0.40)\end{array}$ & $\begin{array}{c}2.95 \\
(0.64)\end{array}$ \\
\hline Market Return & $\begin{array}{c}0.17 * * * \\
(3.96)\end{array}$ & $\begin{array}{c}0.20 * * * \\
(4.10)\end{array}$ & $\begin{array}{c}0.23 * * * \\
(3.85)\end{array}$ & $\begin{array}{l}0.60 * \\
(1.91)\end{array}$ & $\begin{array}{c}0.25 * * * \\
(3.68)\end{array}$ \\
\hline Real GDP Growth Rate & $\begin{array}{c}-0.35 \\
(-0.76)\end{array}$ & $\begin{array}{c}-0.31 \\
(-0.66)\end{array}$ & $\begin{array}{c}-0.51 \\
(-1.15)\end{array}$ & $\begin{array}{c}-0.39 \\
(-0.95)\end{array}$ & $\begin{array}{c}-0.26 \\
(-0.61)\end{array}$ \\
\hline Personal Income & $\begin{array}{c}-0.01 \\
(-0.93)\end{array}$ & $\begin{array}{c}-0.01 \\
(-1.03)\end{array}$ & $\begin{array}{l}-0.01 \\
(-0.66)\end{array}$ & $\begin{array}{c}0.01 \\
(0.68)\end{array}$ & $\begin{array}{l}-0.01 \\
(-0.54)\end{array}$ \\
\hline Unemployment Rate & $\begin{array}{l}-1.26 \\
(-1.56)\end{array}$ & $\begin{array}{c}-1.09 \\
(-1.60)\end{array}$ & $\begin{array}{c}-1.53 \\
(-1.63)\end{array}$ & $\begin{array}{c}-0.76 \\
(-1.50)\end{array}$ & $\begin{array}{c}-0.53 \\
(-0.74)\end{array}$ \\
\hline Year Fixed Effects & $\mathrm{Y}$ & $\mathrm{Y}$ & $\mathrm{Y}$ & $\mathrm{Y}$ & $\mathrm{Y}$ \\
\hline Industry Fixed Effects & $\mathrm{Y}$ & $\mathrm{Y}$ & $\mathrm{Y}$ & $\mathrm{Y}$ & $\mathrm{Y}$ \\
\hline State Fixed Effects & Y & Y & Y & Y & $\mathrm{Y}$ \\
\hline State Cluster & $\mathrm{Y}$ & $\mathrm{Y}$ & $\mathrm{Y}$ & Y & $\mathrm{Y}$ \\
\hline $\mathrm{N}$ & 1,524 & 1,524 & 1,524 & 1,485 & 1,524 \\
\hline Adjusted $R^{2}$ & 0.2635 & 0.2636 & 0.2644 & 0.1498 & 0.2621 \\
\hline
\end{tabular}


Table 5: The Mitigating Role of Political Money Contributions

This table presents the analysis on the relation between policy risk and underpricing using initially the ordinary least squares (OLS) method and then the Propensity Score Matching (PSM) procedure. Also, to correct for a possible selection bias in a different way, we report the results of the second stage of the estimation of the Heckman (1979) model in columns (3) and (4) of Panel B. The dependent variable, underpricing, is calculated as the percentage changes from the first day closing price to offer price. PAI is the Political Alignment Index in the fiscal year prior to the IPO. Control variables are: Company Age, Leverage, Proceeds, EPS, VC, Underwriter, Internet, Technology, Nasdaq, Overhang, Market Return, Real GDP Growth, Personal Income and Unemployment Rate Year, Industry and State Dummies. We also report the Wald test $F$-statistics that coefficients of PAI are the same between the subsamples. T-statistics are included in parentheses, are adjusted for heteroskedasticity robust standard errors and clustered by state. ***, **, and * denote significance at the $1 \%, 5 \%$, and $10 \%$ levels, respectively. All variables are defined in Appendix A.

Panel A: The Mitigating Role of Active Political Strategies on the PAI-Underpricing Link using OLS Method

\begin{tabular}{ccc}
\hline & $(1)$ & $(2)$ \\
\hline PAI & $(\mathrm{PMC}=0)$ & $(\mathrm{PMC}=1)$ \\
\hline Control Variables & $9.14 * * *$ & -5.74 \\
Year Fixed Effects & $(3.69)$ & $(-1.30)$ \\
Industry Fixed Effects & $\mathrm{Y}$ & $\mathrm{Y}$ \\
State Fixed Effects & $\mathrm{Y}$ & $\mathrm{Y}$ \\
State Cluster & $\mathrm{Y}$ & $\mathrm{Y}$ \\
$\mathrm{N}$ & $\mathrm{Y}$ & $\mathrm{Y}$ \\
Adjusted $R^{2}$ & $\mathrm{Y}$ & 173 \\
Wald $\chi 2$ test & 1,351 & 0.5484 \\
\hline
\end{tabular}

Panel B: The Mitigating Role of Active Political Strategies on the PAI-Underpricing Link using the PSM and the twostage Heckman Procedure

\begin{tabular}{|c|c|c|c|c|}
\hline & \multicolumn{2}{|c|}{ PSM: One-to-one matching } & \multicolumn{2}{|c|}{ Heckman Procedure } \\
\hline & $(1)$ & $(2)$ & $(3)$ & $(4)$ \\
\hline & $(\mathrm{PMC}=0)$ & $(\mathrm{PMC}=1)$ & $(\mathrm{PMC}=0)$ & $(\mathrm{PMC}=1)$ \\
\hline PAI & $\begin{array}{c}14.85^{* * *} * \\
(3.20)\end{array}$ & $\begin{array}{c}315 \\
(1.62)\end{array}$ & $\begin{array}{c}10.11 * * * \\
(4.58)\end{array}$ & $\begin{array}{c}-4.40 \\
(-0.98)\end{array}$ \\
\hline Inv. Mills Ratio & & & $\begin{array}{c}0.01 \\
(0.75)\end{array}$ & $\begin{array}{l}-0.01 * \\
(1.91)\end{array}$ \\
\hline Control Variables & $\mathrm{Y}$ & $\mathrm{Y}$ & $\mathrm{Y}$ & $\mathrm{Y}$ \\
\hline $\mathrm{N}$ & 149 & 149 & 1,351 & 173 \\
\hline Adjusted $R^{2}$ & 0.3818 & 0.4544 & 0.3515 & 0.5312 \\
\hline Wald $\chi 2$ test & \multicolumn{2}{|c|}{$0.04 * *$} & \multicolumn{2}{|c|}{$0.00 * * *$} \\
\hline
\end{tabular}


Table 6: Industry Effects and State's Economic Freedom Index

This Table presents the results of the mitigating role of the industry and state infrastructure. The dependent variable is the IPO underpricing. Models (1) and (2) present analysis on the relation between PAI and underpricing using ordinary least squares (OLS) on the Politically Sensitive Industries (PSI) and Economic Freedom (EF) subsamples, respectively. PSI is an indicator variable set to one for firms that belong to the following industries: Tobacco Products, Pharmaceuticals, Healthcare Services, Defense, Petroleum and Natural Gas, Telecommunications and Transportation where the industry classifications are based on Fama-French 48 industries (following Herron et al., 1999). Control variables are: Company Age, Leverage, Proceeds, EPS, VC, Underwriter, Internet, Technology, Nasdaq, Overhang, Market Return, Real GDP Growth, Personal Income and Unemployment Rate Year, Industry and State Dummies. We also report the Wald test F-statistics that coefficients of PAI are the same between the subsamples. T-statistics are included in the parentheses and are adjusted for heteroskedasticity robust standard errors and clustered by state. $* * *, * *$, and $*$ denote significance at the $1 \%, 5 \%$, and $10 \%$ levels, respectively. All variables are defined in Appendix A.

(1)

(2)

\begin{tabular}{ccccc}
\hline & \multicolumn{2}{c}{ Politically Sensitive Industries (PSI) } & \multicolumn{2}{c}{ Economic Freedom (EF) } \\
\hline & PSI & Non-PSI & High EF & Low EF \\
\hline PAI & $10.83^{* * *}$ & $4.45^{* *}$ & $8.24^{*}$ & $23.48^{* * *}$ \\
Control variables & $(6.15)$ & $(2.33)$ & $(171)$ & $(3.97)$ \\
Year Fixed Effects & $\mathrm{Y}$ & $\mathrm{Y}$ & $\mathrm{Y}$ & $\mathrm{Y}$ \\
Industry Fixed Effects & $\mathrm{Y}$ & $\mathrm{Y}$ & $\mathrm{Y}$ & $\mathrm{Y}$ \\
State Fixed Effects & $\mathrm{Y}$ & $\mathrm{Y}$ & $\mathrm{Y}$ & $\mathrm{Y}$ \\
State Cluster & $\mathrm{Y}$ & $\mathrm{Y}$ & $\mathrm{Y}$ & $\mathrm{Y}$ \\
$\mathrm{N}$ & 459 & 1,065 & 597 & $\mathrm{Y}$ \\
Adjusted $R^{2}$ & 0.1754 & 0.2885 & 0.3276 & 687 \\
Wald $\chi 2$ test & & $0.03 * *$ & & $0.04 * *$ \\
\hline
\end{tabular}

Table 7: Cross-Sectional Tests: Effects of Firm Characteristics on the Association Between PAI and Underpricing

This Table shows the results of OLS regressions on IPO underpricing using firm-subsamples. Columns (1) and (2) present the coefficient estimates of PAI for technology and non-technology firms while columns (3) and (4) display the PAI coefficients by firm age. Columns (5) and (6) report the results of PAI on IPO initial returns on the subsamples of firms with high and low agency conflicts. A firm is classified as large (small) if its proceeds are larger (smaller) than the sample median. Similarly, a firm is considered young (old) if its age is greater (smaller) than the sample median. Using the same logic, a firm has high agency problems if its cash flows are higher (smaller) than the sample median. Control variables are: Company Age, Leverage, Proceeds, EPS, VC, Underwriter, Internet, Technology, Nasdaq, Overhang, Market Return, Real GDP Growth, Personal Income and Unemployment Rate Year, Industry and State Dummies. We also report the Wald test $F$-statistics that coefficients of PAI are the same between the subsamples. T-statistics are included in the parentheses, are adjusted for heteroskedasticity robust standard errors and clustered by state. $* * *, * *$, and $*$ denote significance at the $1 \%, 5 \%$, and $10 \%$ levels, respectively. All variables are defined in Appendix A.

\begin{tabular}{|c|c|c|c|c|c|c|}
\hline & $\begin{array}{l}\text { Tech } \\
\text { firms }\end{array}$ & $\begin{array}{l}\text { Non-Tech } \\
\text { firms }\end{array}$ & $\begin{array}{l}\text { Young } \\
\text { firms }\end{array}$ & $\begin{array}{l}\text { Old } \\
\text { firms }\end{array}$ & $\begin{array}{l}\text { High Agency } \\
\text { Conflicts }\end{array}$ & $\begin{array}{c}\text { Low Agency } \\
\text { Conflicts }\end{array}$ \\
\hline & $(1)$ & (2) & (3) & (4) & $(5)$ & (6) \\
\hline PAI & $\begin{array}{c}14.85 * * * \\
(2.75)\end{array}$ & $\begin{array}{c}2.55 \\
(1.55)\end{array}$ & $\begin{array}{c}12.38 * * * \\
(3.74)\end{array}$ & $\begin{array}{l}2.86^{*} \\
(1.71)\end{array}$ & $\begin{array}{c}7.20^{* * * *} \\
(5.30)\end{array}$ & $\begin{array}{c}1.93 \\
(1.25)\end{array}$ \\
\hline Control Variables & $\mathrm{Y}$ & $\mathrm{Y}$ & $\mathrm{Y}$ & $\mathrm{Y}$ & $\mathrm{Y}$ & $\mathrm{Y}$ \\
\hline Year Fixed Effects & $\mathrm{Y}$ & $\mathrm{Y}$ & Y & $\mathrm{Y}$ & $\mathrm{Y}$ & $\mathrm{Y}$ \\
\hline Industry Fixed Effects & $\mathrm{Y}$ & $\mathrm{Y}$ & $\mathrm{Y}$ & $\mathrm{Y}$ & $\mathrm{Y}$ & $\mathrm{Y}$ \\
\hline State Fixed Effects & $\mathrm{Y}$ & $\mathrm{Y}$ & Y & $\mathrm{Y}$ & $\mathrm{Y}$ & $\mathrm{Y}$ \\
\hline State Cluster & $\mathrm{Y}$ & $\mathrm{Y}$ & Y & $\mathrm{Y}$ & $\mathrm{Y}$ & $\mathrm{Y}$ \\
\hline $\mathrm{N}$ & 544 & 980 & 719 & 805 & 1,011 & 513 \\
\hline Adjusted $R^{2}$ & 0.3188 & 0.2034 & 0.3744 & 0.2414 & 0.2423 & 0.3812 \\
\hline Wald $\chi^{2}$ test & \multicolumn{2}{|c|}{$0.03^{* *}$} & \multicolumn{2}{|c|}{$0.02 * *$} & \multicolumn{2}{|c|}{$0.02 * *$} \\
\hline
\end{tabular}


Table 8: Robustness Analysis and Additional Tests: Alternative Proxies of Policy Risk

This Table presents the results of OLS regressions on IPO underpricing using alternative policy risk proxies (PolRisk1, PolRisk2, PolRisk3, PolRisk4, and PolRIsk5), following Bradley et al. (2016). The dependent variable is IPO underpricing. PolRisk1 is the (BilNum) natural logarithm of the number of bills introduced in Congress by politicians from a given state. PolRisk2 is the PAI index multiplied by the monthly national policy uncertainty index (EPU) of Baker et al. (2016). PolRisk3 is BilNum multiplied by the monthly EPU, where BilNum is the natural logarithm of the number of bills introduced in Congress by politicians from a given state. PolRisk4 is the partisan conflict index (PCI) of Azzimonti (2017), and finally PolRisk5 is PAI multiplied by the PCI. Model (1) displays the regression results using PolRisk1 instead of PAI, while models (2), (3), (4), and (5) replace PAI with PolRisk2, PolRisk3, PolRisk4, PolRisk5, respectively. Control variables are: Company Age, Leverage, Proceeds, EPS, VC, Underwriter, Internet, Technology, Nasdaq, Overhang, Market Return, Real GDP Growth, Personal Income and Unemployment Rate Year, Industry and State Dummies. T-statistics are included in the parentheses, are adjusted for heteroskedasticity robust standard errors and clustered by state. ***,**, and * denote significance at the $1 \%, 5 \%$, and $10 \%$ levels, respectively. All variables are defined in Appendix A.

\begin{tabular}{|c|c|c|c|c|c|}
\hline & $(1)$ & (2) & (3) & $(4)$ & $(5)$ \\
\hline PolRisk1 & $\begin{array}{c}0.84 * * * \\
(4.00)\end{array}$ & & & & \\
\hline PolRisk2 & & $\begin{array}{l}0.04 * \\
(1.91)\end{array}$ & & & \\
\hline PolRisk3 & & & $\begin{array}{c}0.06 * * * \\
(4.06)\end{array}$ & & \\
\hline PolRisk4 & & & & $\begin{array}{c}0.10 * * \\
(2.05)\end{array}$ & \\
\hline PolRisk5 & & & & & $\begin{array}{c}0.07 * * * \\
(4.16)\end{array}$ \\
\hline Control variables & Y & $\mathrm{Y}$ & $\mathrm{Y}$ & $\mathrm{Y}$ & $\mathrm{Y}$ \\
\hline Year Fixed Effects & Y & $\mathrm{Y}$ & $\mathrm{Y}$ & $\mathrm{Y}$ & Y \\
\hline Industry Fixed Effects & Y & $\mathrm{Y}$ & Y & Y & Y \\
\hline State Fixed Effects & $\mathrm{Y}$ & $\mathrm{Y}$ & $\mathrm{Y}$ & $\mathrm{Y}$ & Y \\
\hline State Cluster & $\mathrm{Y}$ & $\mathrm{Y}$ & $\mathrm{Y}$ & $\mathrm{Y}$ & $\mathrm{Y}$ \\
\hline $\mathrm{N}$ & 1,524 & 1,524 & 1,524 & 1,524 & 1,524 \\
\hline Adjusted $R^{2}$ & 0.2635 & 0.2626 & 0.2632 & 0.2636 & 0.2645 \\
\hline
\end{tabular}


Table 9: Robustness Analysis and Additional Tests: Industry- and State Fixed Effects and Influential States This Table shows the results of additional robustness tests. The dependent variable is IPO underpricing. Panel A displays the effect of PAI on underpricing excluding industry and state fixed effects. Panel B reruns the baseline results after excluding influential states high/low PAI. The following models describe in detail the specification of Panel A. Model (1) and (2) consider alternative industry classifications. Model (3) reports the results without industry fixed effects. Model (4) presents the result without industry- and state-fixed effects. Control variables are: Company Age, Leverage, Proceeds, EPS, VC, Underwriter, Internet, Technology, Nasdaq, Overhang, Market Return, Real GDP Growth, Personal Income and Unemployment Rate Year, Industry and State Dummies. T-statistics are included in the parentheses, are adjusted for heteroskedasticity robust standard errors and clustered by state. $* * *, * *$, and $*$ denote significance at the $1 \%, 5 \%$, and $10 \%$ levels, respectively. All variables are defined in Appendix A.

\begin{tabular}{|c|c|c|c|c|}
\hline \multicolumn{5}{|c|}{ Panel A: Excluding Industry and State Fixed Effects } \\
\hline & FF17 & FF30 & Excluding industry-fixed effects & $\begin{array}{l}\text { Excluding industry- and state- } \\
\text { fixed effects }\end{array}$ \\
\hline & (1) & (2) & (3) & $(4)$ \\
\hline PAI & $\begin{array}{c}5.24 * * * \\
(4.12)\end{array}$ & $\begin{array}{c}6.23 * * * \\
(4.43)\end{array}$ & $\begin{array}{l}5.24 * * * \\
(3.82)\end{array}$ & $\begin{array}{c}5.38 * * * \\
(3.42)\end{array}$ \\
\hline Control variables & $\mathrm{Y}$ & Y & $\mathrm{Y}$ & $\mathrm{Y}$ \\
\hline Year Fixed Effects & Y & Y & Y & $\mathrm{Y}$ \\
\hline $\begin{array}{l}\text { Industry Fixed } \\
\text { Effects }\end{array}$ & $\mathrm{Y}$ & $\mathrm{Y}$ & $\mathrm{N}$ & $\mathrm{N}$ \\
\hline State Fixed Effects & $\mathrm{Y}$ & $\mathrm{Y}$ & $\mathrm{Y}$ & $\mathrm{N}$ \\
\hline State Cluster & $\mathrm{Y}$ & $\mathrm{Y}$ & Y & Y \\
\hline $\mathrm{N}$ & 1,524 & 1,524 & 1,524 & 1,524 \\
\hline Adjusted $R^{2}$ & 0.2439 & 0.2577 & 0.2301 & 0.2173 \\
\hline
\end{tabular}

\begin{tabular}{|c|c|c|c|c|c|c|}
\hline \multicolumn{7}{|c|}{ Panel B: Excluding Potential Influential States with High/Low PAI } \\
\hline & \multicolumn{3}{|c|}{ States with High PAI } & \multicolumn{3}{|c|}{ States with Low PAI } \\
\hline & Massachusetts & California & New York & Texas & Georgia & Tennessee \\
\hline & $(1)$ & $(2)$ & (3) & (4) & $(5)$ & (6) \\
\hline PAI & $\begin{array}{l}5.10^{*} \\
(1.79)\end{array}$ & $\begin{array}{c}7.69 * * * \\
(3.01)\end{array}$ & $\begin{array}{c}6.89 * * * \\
(3.61)\end{array}$ & $\begin{array}{l}9.91 * * * \\
(6.79)\end{array}$ & $\begin{array}{c}6.23 * * * \\
(3.41)\end{array}$ & $\begin{array}{c}6.81 * * * \\
(3.77)\end{array}$ \\
\hline Control variables & $\mathrm{Y}$ & $\mathrm{Y}$ & $\mathrm{Y}$ & $\mathrm{Y}$ & $\mathrm{Y}$ & $\mathrm{Y}$ \\
\hline Year Fixed Effects & $\mathrm{Y}$ & $\mathrm{Y}$ & $\mathrm{Y}$ & $\mathrm{Y}$ & $\mathrm{Y}$ & $\mathrm{Y}$ \\
\hline $\begin{array}{c}\text { Industry Fixed } \\
\text { Effects }\end{array}$ & Y & $\mathrm{Y}$ & $\mathrm{Y}$ & $\mathrm{Y}$ & Y & Y \\
\hline State Fixed Effects & $\mathrm{Y}$ & $\mathrm{Y}$ & Y & $\mathrm{Y}$ & $\mathrm{Y}$ & $\mathrm{Y}$ \\
\hline State Cluster & Y & $\mathrm{Y}$ & $\mathrm{Y}$ & $\mathrm{Y}$ & $\mathrm{Y}$ & Y \\
\hline $\mathrm{N}$ & 1,380 & 1,081 & 1,451 & 1.371 & 1,487 & 1,497 \\
\hline Adjusted $R^{2}$ & 0.2638 & 0.2881 & 0.2733 & 0.2606 & 0.2649 & 0.2643 \\
\hline
\end{tabular}


Table 10: The Effect of PAI on Post-IPO Return Volatility

This Table shows the results of additional tests using post-IPO volatility measures. Panel A displays the summary statistics of Post-IPO Return and Idiosyncratic Volatility. Panel B and C present the results of the impact of PAI on Post-IPO Return and Idiosyncratic Volatility. Post-IPO return volatility is the dependent variable and is computed over +5 to +26 (trading) days post-IPO in Column (1), +5 to +63 days post-IPO in Column (2), +5 to +126 days post-IPO in Column (3), and +5 to +189 days post-IPO in Column (4), 5 to +252 days post-IPO in Column (5), 5 to +504 days post-IPO in Column (6), 5 to +756 days post-IPO in Column (7) (first week is ignored since there may be unusual trading activity because of share flipping). Control variables are: Company Age, Leverage, Proceeds, EPS, VC, Underwriter, Internet, Technology, Nasdaq, Overhang, Market Return, Real GDP Growth, Personal Income and Unemployment Rate Year, Industry and State Dummies. T-statistics are included in the parentheses, are adjusted for heteroskedasticity robust standard errors and clustered by state. $* * *, * *$, and $*$ denote significance at the $1 \%, 5 \%$, and $10 \%$ levels, respectively. All variables are defined in Appendix A.

\begin{tabular}{|c|c|c|c|c|}
\hline \multicolumn{5}{|c|}{ Panel A: Descriptive Statistics of Post-IPO Volatility Measures } \\
\hline & Full Sample & High PAI & Low PAI & Difference \\
\hline & Mean & Mean & Mean & p-value \\
\hline \multicolumn{5}{|l|}{ Post-IPO Return volatility } \\
\hline+5 to +21 days post-IPO & 0.039 & 0.044 & 0.034 & 0.0000 \\
\hline+5 to +63 days post-IPO & 0.041 & 0.045 & 0.038 & 0.0000 \\
\hline+5 to +126 days post-IPO & 0.042 & 0.045 & 0.038 & 0.0000 \\
\hline+5 to +189 days post-IPO & 0.043 & 0.046 & 0.039 & 0.0000 \\
\hline+5 to +252 days post-IPO & 0.043 & 0.046 & 0.039 & 0.0000 \\
\hline+5 to +504 days post-IPO & 0.178 & 0.188 & 0.169 & 0.0004 \\
\hline+5 to +756 days post-IPO & 0.175 & 0.179 & 0.172 & 0.1332 \\
\hline \multicolumn{5}{|c|}{ Post-IPO Idiosyncratic Volatility } \\
\hline+5 to +21 days post-IPO & 0.038 & 0.042 & 0.034 & 0.0000 \\
\hline+5 to +63 days post-IPO & 0.040 & 0.043 & 0.037 & 0.0000 \\
\hline+5 to +126 days post-IPO & 0.041 & 0.044 & 0.037 & 0.0000 \\
\hline+5 to +189 days post-IPO & 0.041 & 0.044 & 0.038 & 0.0000 \\
\hline+5 to +252 days post-IPO & 0.041 & 0.043 & 0.038 & 0.0000 \\
\hline+5 to +504 days post-IPO & 0.040 & 0.041 & 0.038 & 0.0075 \\
\hline+5 to +756 days post-IPO & 0.038 & 0.039 & 0.038 & 0.2000 \\
\hline
\end{tabular}

\begin{tabular}{|c|c|c|c|c|c|c|c|}
\hline \multicolumn{8}{|c|}{ Panel B: Impact of PAI on Post-IPO Return Volatility } \\
\hline & (1) & (2) & (3) & (4) & $(5)$ & (6) & (7) \\
\hline PAI & $\begin{array}{c}0.01 * * * \\
(2.65)\end{array}$ & $\begin{array}{c}0.01 * * \\
(2.27)\end{array}$ & $\begin{array}{c}0.01 * * * \\
(2.99)\end{array}$ & $\begin{array}{c}0.01 * * * \\
(3.34)\end{array}$ & $\begin{array}{c}0.01 * * \\
(2.18\end{array}$ & $\begin{array}{c}-0.01 \\
(-0.71)\end{array}$ & $\begin{array}{c}-0.01 \\
(-1.24)\end{array}$ \\
\hline Control variables & $\mathrm{Y}$ & $\mathrm{Y}$ & $\mathrm{Y}$ & $\mathrm{Y}$ & Y & $\mathrm{Y}$ & Y \\
\hline Year Fixed Effects & Y & Y & Y & Y & Y & $\mathrm{Y}$ & Y \\
\hline Industry Fixed Effects & Y & Y & Y & Y & Y & Y & Y \\
\hline State Fixed Effects & $\mathrm{Y}$ & Y & $\mathrm{Y}$ & $\mathrm{Y}$ & $\mathrm{Y}$ & $\mathrm{Y}$ & Y \\
\hline State Cluster & $\mathrm{Y}$ & $\mathrm{Y}$ & $\mathrm{Y}$ & $\mathrm{Y}$ & $\mathrm{Y}$ & $\mathrm{Y}$ & $\mathrm{Y}$ \\
\hline $\mathrm{N}$ & 1,183 & 1,183 & 1,183 & 1,183 & 1,183 & 1,107 & 918 \\
\hline Adjusted $R^{2}$ & 0.4975 & 0.5950 & 0.6554 & 0.6743 & 0.6407 & 0.5110 & 0.4490 \\
\hline \multicolumn{8}{|c|}{ Panel C: Impact of PAI on Post-IPO Idiosyncratic Volatility } \\
\hline & $(1)$ & $(2)$ & (3) & (4) & $(5)$ & $(6)$ & $(7)$ \\
\hline PAI & $\begin{array}{c}0.01 \\
(1.35)\end{array}$ & $\begin{array}{c}0.01 * * * \\
(2.89)\end{array}$ & $\begin{array}{c}0.01 * * \\
(2.52)\end{array}$ & $\begin{array}{c}0.01 * * \\
(2.41)\end{array}$ & $\begin{array}{c}0.01 * * * \\
(3.10)\end{array}$ & $\begin{array}{c}-0.01 \\
(-0.73)\end{array}$ & $\begin{array}{c}-0.01 \\
(-0.30)\end{array}$ \\
\hline Control variables & Y & $\mathrm{Y}$ & Y & $\mathrm{Y}$ & $\mathrm{Y}$ & Y & Y \\
\hline Year Fixed Effects & Y & Y & $\mathrm{Y}$ & $\mathrm{Y}$ & $\mathrm{Y}$ & Y & Y \\
\hline Industry Fixed Effects & Y & Y & Y & Y & $\mathrm{Y}$ & Y & Y \\
\hline State Fixed Effects & $\mathrm{Y}$ & $\mathrm{Y}$ & $\mathrm{Y}$ & $\mathrm{Y}$ & $\mathrm{Y}$ & Y & Y \\
\hline State Cluster & Y & $\mathrm{Y}$ & Y & Y & $\mathrm{Y}$ & $\mathrm{Y}$ & Y \\
\hline $\mathrm{N}$ & 1,176 & 1,174 & 1,172 & 1,166 & 1,156 & 1,026 & 842 \\
\hline Adjusted $R^{2}$ & 0.4409 & 0.5817 & 0.6315 & 0.6014 & 0.5896 & 0.5514 & 0.5497 \\
\hline
\end{tabular}


Table 11: The Effect of PAI on Investment Measures

This Table shows the results of additional tests using post-IPO investment measures. Model (1) considers as dependent variable the sum of R\&D and CAPEX over the sales on the issue year. Models (2) and (3) report the results using as dependent variables the investment measures of CAPEX and R\&D. R\&D is the ratio of total R\&D expense to total sales in the IPO year. CAPEX is the ratio of total capital expenditures to total sales in the IPO year. Control variables are: Company Age, Leverage, Proceeds, EPS, VC, Underwriter, Internet, Technology, Nasdaq, Overhang, Market Return, Real GDP Growth, Personal Income and Unemployment Rate Year, Industry and State Dummies. T-statistics are included in the parentheses, are adjusted for heteroskedasticity robust standard errors and clustered by state. ***, **, and * denote significance at the $1 \%, 5 \%$, and $10 \%$ levels, respectively. All variables are defined in Appendix A.

\begin{tabular}{cccc}
\hline & R\&D and CAPEX & CAPEX & R\&D \\
\hline & $(1)$ & $(2)$ & $(3)$ \\
\hline PAI & $-0.73^{* *}$ & $-0.39^{* *}$ & $-0.34^{*}$ \\
Control variables & $(-2.28)$ & $(-2.38)$ & $\mathrm{Y}$ \\
Year Fixed Effects & $\mathrm{Y}$ & $\mathrm{Y}$ & $\mathrm{Y}$ \\
Industry Fixed Effects & $\mathrm{Y}$ & $\mathrm{Y}$ & $\mathrm{Y}$ \\
State Fixed Effects & $\mathrm{Y}$ & $\mathrm{Y}$ & $\mathrm{Y}$ \\
State Cluster & $\mathrm{Y}$ & $\mathrm{Y}$ & $\mathrm{Y}$ \\
$\mathrm{N}$ & $\mathrm{Y}$ & $\mathrm{Y}$ & 1,183 \\
Adjusted $R^{2}$ & 1,183 & 1,183 & 0.4685 \\
\hline
\end{tabular}


Table 12: Long-Term Implication of PAI

This Table illustrates the estimation of Cox proportional hazards model of the probability of failure and time-to failure as well as the estimation of the Accelerated Failure Time (AFT) model. In Model (1), our dependent variable is whether or not a firm survived 5 years after its IPO. The baseline hazard function $h_{0}(t)$ is estimated using the following Cox model: $h(t)=h_{0}(t)\left[\beta_{1} P A I_{i, t}+\beta_{2}\right.$ Control Variables $_{i}+$ Fixed Effects], where $t$ is the time to failure (i.e., the duration to the delisting date). In Model (2), our dependent variable is the natural logarithm of the time to delist (survival time) which is measured in months. With respect to the AFT model, we estimate the following specific model where the natural logarithm of the time to delist (survival time) is presented as a linear function of the covariates: $\operatorname{Ln}\left(T_{j}\right)=\beta_{0}+$ $\beta_{1}$ Control Variables $i+$ Fixed Effects $+\varepsilon_{j}$, where $\operatorname{Ln}\left(T_{j}\right)$ is the natural logarithm of the survival time or time to failure.The Weibull distribution was selected based on the Akaike Information Criterion (AIC). Time ratios are the exponentiated coefficients, $\exp (\beta)$, and measure the extent to which changes in covariates accelerate or decelerate the occurrence of event (delisting). Regressions control for industry and year fixed effects whose coefficients are suppressed. T-statistics are included in the parentheses. $* * *, * *$, and $*$ denote significance at the $1 \%, 5 \%$, and $10 \%$ levels, respectively. All variables are defined in Appendix A.

\begin{tabular}{|c|c|c|c|c|}
\hline & \multicolumn{2}{|c|}{$\frac{\text { Cox Model }}{(1)}$} & \multicolumn{2}{|c|}{$\frac{\text { AFT Model }}{(2)}$} \\
\hline & Coefficient & Hazard Ratio & Coefficient & Time Ratio \\
\hline PAI & $\begin{array}{c}0.52 * * * \\
(3.10)\end{array}$ & 1.688 & $\begin{array}{c}-0.45 * * * \\
(-3.39)\end{array}$ & 0.638 \\
\hline Firm Age & $\begin{array}{l}0.07^{*} \\
(1.66)\end{array}$ & 1.073 & $\begin{array}{r}-0.09 * * \\
(-2.47)\end{array}$ & 0.914 \\
\hline Leverage & $\begin{array}{l}-0.10 \\
(-0.89)\end{array}$ & 0.905 & $\begin{array}{c}0.07 \\
(0.82)\end{array}$ & 1.073 \\
\hline Proceeds & $\begin{array}{l}-0.10^{* *} \\
(-2.06)\end{array}$ & 0.903 & $\begin{array}{l}0.10 * * \\
(2.55)\end{array}$ & 1.105 \\
\hline EPS & $\begin{array}{c}0.12 \\
(1.30)\end{array}$ & 1.129 & $\begin{array}{l}-0.05 \\
(-0.67)\end{array}$ & 0.951 \\
\hline Overhang & $\begin{array}{c}0.01 \\
(0.48)\end{array}$ & 1.002 & $\begin{array}{l}-0.01 \\
(-0.26)\end{array}$ & 0.990 \\
\hline $\mathrm{VC}$ & $\begin{array}{c}0.04 \\
(0.35)\end{array}$ & 1.039 & $\begin{array}{c}-0.17 * * \\
(-2.00)\end{array}$ & 0.844 \\
\hline Underwriter & $\begin{array}{l}-0.16^{*} \\
(-1.67)\end{array}$ & 0.847 & $\begin{array}{c}0.30 * * * \\
(3.66)\end{array}$ & 1.350 \\
\hline Internet & $\begin{array}{l}-0.17 \\
(-1.08)\end{array}$ & 0.841 & $\begin{array}{l}-0.13 \\
(-1.15)\end{array}$ & 0.878 \\
\hline Technology & $\begin{array}{l}-0.32 \\
(-1.41)\end{array}$ & 0.723 & $\begin{array}{c}0.20 \\
(1.11)\end{array}$ & 1.221 \\
\hline Nasdaq & $\begin{array}{l}-0.10 \\
(-0.83)\end{array}$ & 0.905 & $\begin{array}{l}-0.03 \\
(0.36)\end{array}$ & 0.970 \\
\hline Market Return & $\begin{array}{l}-1.59 \\
(-1.40)\end{array}$ & 0.203 & $\begin{array}{c}0.98 \\
(1.03)\end{array}$ & 2.664 \\
\hline Real GDP Growth Rate & $\begin{array}{l}-0.01 \\
(-0.27)\end{array}$ & 0.994 & $\begin{array}{l}-0.01 \\
(-0.58)\end{array}$ & 0.990 \\
\hline Personal Income & $\begin{array}{c}-0.01 * * * \\
(-4.55)\end{array}$ & 0.999 & $\begin{array}{c}0.01 * * * \\
(4.65)\end{array}$ & 1.010 \\
\hline Unemployment Rate & $\begin{array}{c}-0.42 * * * \\
(-5.30)\end{array}$ & 0.656 & $\begin{array}{c}0.61 * * * \\
(5.45)\end{array}$ & 1.840 \\
\hline $\begin{array}{l}\text { Industry, Year and State } \\
\text { FE }\end{array}$ & $\mathrm{Y}$ & & $\mathrm{Y}$ & \\
\hline Chi-Square & 841.96 & & $1,977.42$ & \\
\hline $\mathrm{N}$ & 1,062 & & 1,062 & \\
\hline
\end{tabular}


Figure 1: Map of PAI

This figure shows the map of PAI in forty six states from 2000 to 2016. For each state, we compute the average PAI during the sample period.

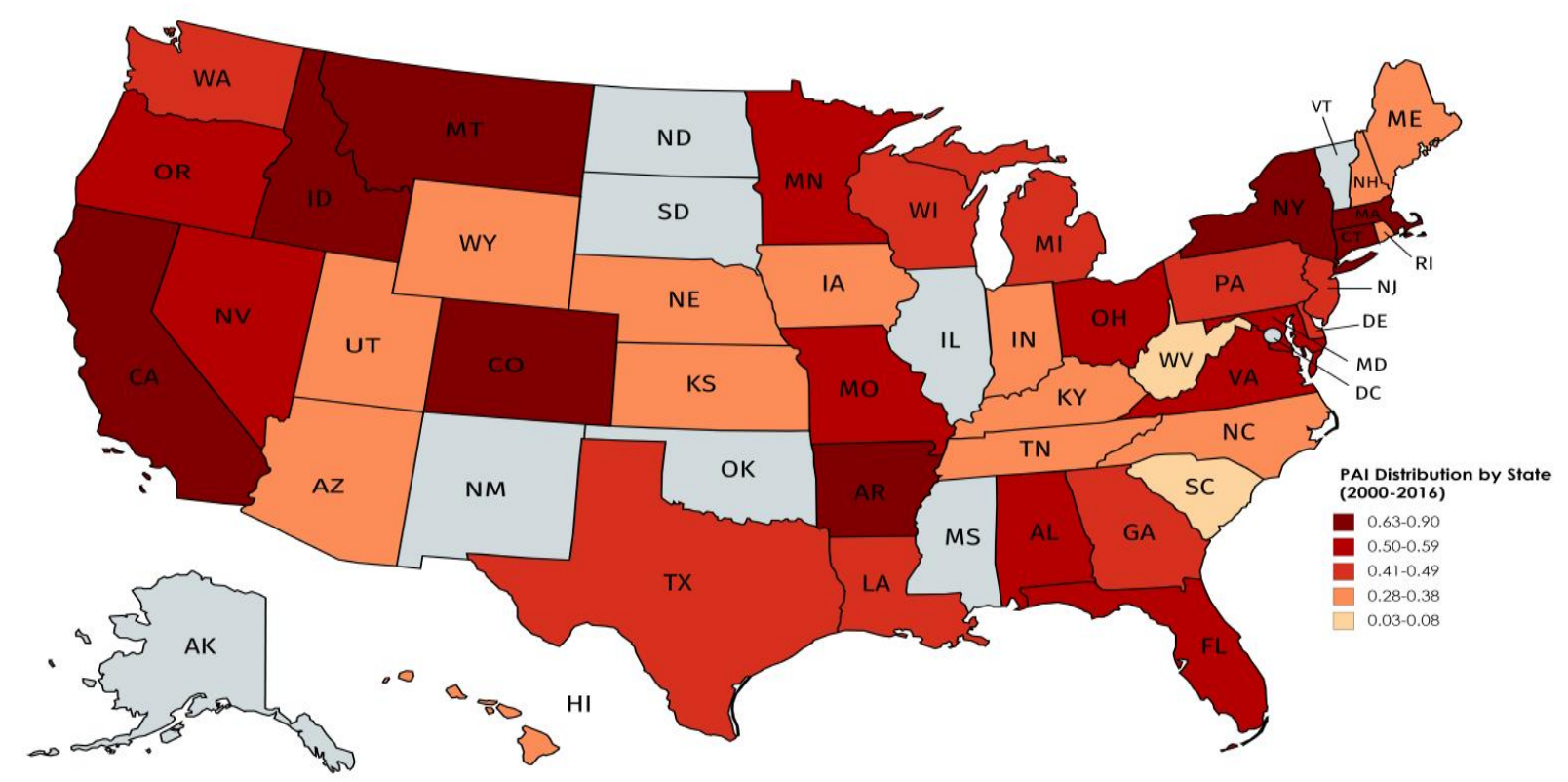




\section{Internet Appendix}

This appendix provides the following empirical tests:

- Table 1 presents the correlation matrices of IPO pricing, firm fundamentals and other state variables.

- Table 2 presents the yearly distribution of the Partisan Conflict Index and the Index of Economic Freedom.

- Table 3 presents the legislative activities for the PAI sub-groups.

- Table 4 presents an indicative list of ten companies located in low (high) PAI stated including their underpricing.

- Table 5 presents an indicative list of ten companies located in low (high) PAI stated including their survival rates.

- Table 6 presents the top (bottom) ten Industries based on the PAI distribution.

- Table 7 presents the top (bottom) ten states based on the number of IPO survivors.

- Table 8 presents the descriptive statistics of firm characteristics based on whether firms engage in Political Money Contributions (PMC).

- Table 9 presents the results of OLS regressions of PAI on IPO underpricing for along different political periods

- Table 10 reports the tests for Endogeneity Control and Sample Selection Bias.

- Figure 2 presents a graphical depiction of the PAI distribution by state in 2000 .

- Figure 3 presents a graphical depiction of the PAI distribution by state in 2004 .

- Figure 4 presents a graphical depiction of the PAI distribution by state in 2008 .

- Figure 5 presents a graphical depiction of the PAI distribution by state in 2012.

- Figure 6 presents a graphical depiction of the PAI distribution by state in 2016 .

- Figure 7 presents a breakdown of IPO PMC expenditures by type. 
Table 1: Correlation Matrix

This Table reports pairwise correlations for the main variables employed in our analysis. The sample consists of 1,639 IPOs that floated U.S. stock exchanges from the 1st of January 2000 to the 31st of December 2016. We relied on the Securities Data Company (SDC) Database to retrieve information on IPO deals. Accounting data were collected from CRSP and Compustat databases. Panel A reports correlations of IPO pricing variables, while Panel B presents correlations of IPO offering variables. Finally, Panel C presents the correlations of state-level variables

\begin{tabular}{|c|c|c|c|c|c|c|c|c|}
\hline Panel A: IPO Variables & (1) & (2) & (3) & (4) & (5) & (6) & (7) & (8) \\
\hline \multicolumn{9}{|l|}{ 1. Firm age } \\
\hline 2. Leverage & -0.0091 & & & & & & & \\
\hline 3. Proceeds & 0.0138 & 0.0299 & & & & & & \\
\hline 4. Earnings per Share & 0.0407 & 0.0162 & 0.2563 & & & & & \\
\hline 5. $\mathrm{VC}$ & -0.0257 & -0.0047 & -0.3425 & -0.3725 & & & & \\
\hline 6. Underwriter & -0.0229 & -0.0040 & 0.4594 & 0.1054 & -0.0988 & & & \\
\hline 7. Internet Firm & -0.0178 & -0.0138 & -0.0030 & -0.0609 & 0.1218 & 0.0311 & & \\
\hline 8. Technology Firm & -0.0021 & -0.0470 & -0.1219 & -0.1318 & 0.2740 & -0.0075 & 0.2756 & \\
\hline 9. Nasdaq & -0.0049 & 0.0166 & -0.4474 & -0.2492 & 0.3872 & -0.3561 & 0.0385 & 0.1594 \\
\hline Panel B: State Variables & (10) & (11) & (12) & & & & & \\
\hline \multicolumn{9}{|l|}{ 10. PAI } \\
\hline 11. Real GDP Growth Rate & 0.0666 & & & & & & & \\
\hline 12. Personal Income & 0.1515 & 0.1520 & & & & & & \\
\hline 13. Unemployment Rate & 0.2130 & -0.3684 & 0.3787 & & & & & \\
\hline
\end{tabular}


Table 2: Yearly Distribution of the Partisan Conflict Index and the Index of Economic Freedom This Table presents distributional statistics for a sample of 1,639 U.S. IPOs from 1 January 2000 to 31 December 2016. The IPOs are described by issue-year, whereas in panel B the IPOs are distributed by industry. IPO deals are retrieved from the Securities Data Company (SDC) database.

\begin{tabular}{|c|c|c|}
\hline Year & Partisan Conflict Index & Economic Freedom \\
\hline 2000 & 81.46 & 8.40 \\
\hline 2001 & 79.43 & 8.23 \\
\hline 2002 & 80.04 & 8.22 \\
\hline 2003 & 93.23 & 8.20 \\
\hline 2004 & 92.61 & 8.20 \\
\hline 2005 & 85.99 & 8.02 \\
\hline 2006 & 80.06 & 7.99 \\
\hline 2007 & 84.21 & 8.07 \\
\hline 2008 & 85.67 & 8.01 \\
\hline 2009 & 88.74 & 7.79 \\
\hline 2010 & 132.20 & 7.70 \\
\hline 2011 & 144.23 & 7.65 \\
\hline 2012 & 146.48 & 7.74 \\
\hline 2013 & 166.87 & 7.62 \\
\hline 2014 & 142.77 & 7.67 \\
\hline 2015 & 148.72 & 7.74 \\
\hline
\end{tabular}


Table 3: Legislative Activity and PAI Effect

The Table reports the legislative activities for the PAI sub-groups. Legislative activities are measured as the number of bills introduced and passed by politicians from a particular state. In Panel B, we regress underpricing using OLS method: Underpricing $=\beta_{0}+\beta_{1} P A I+\beta_{2} H i g h L A I+\beta_{3} C P A I * H i g h L A I+\beta_{4}$ Control Variables + Fixed Effects $+\varepsilon_{i}$. Legislative Activity Index (LAI) is the number of bills introduced over the past 4 months in the political district where the firm's headquarters is located. High legislative activity index is a dummy that takes one if the LAI is higher than the median value and zero otherwise.

Number of Bills Introduced

(per state-year)
Number of Bills Passed

(per state-year)

\section{PAI quartile 1}

(Lowest)

PAI quartile 2

PAI quartile 3

PAI quartile 4

(Highest)

Mean difference

(Highest-Lowest)
100.3

106.5

131.2

135.3

$35.0 * * *$

$0.2 * *$ 
Table 4: Underpricing Example of Ten Companies with Headquarters in High (Low) PAI States

The Table reports an indicative list with ten firms operating in high (low) PAI states along with their corresponding underpricing.

\begin{tabular}{|c|c|c|c|c|c|}
\hline \multicolumn{6}{|c|}{ Panel A: Indicative List of Ten Companies Operating in High PAI States } \\
\hline IPO Date & Company & State & $\begin{array}{l}\text { Money left on the } \\
\text { table (in million } \$ \text { ) }\end{array}$ & Initial Returns & PAI \\
\hline $18 / 5 / 2011$ & LinkedIn Corp & California & 352.8 & 109.44 & 0.91 \\
\hline $18 / 4 / 2012$ & Splunk Inc & California & 249.48 & 108.71 & 0.91 \\
\hline $30 / 1 / 2014$ & Ultragenyx Pharmaceutical Inc & California & 122.41 & 101.19 & 0.91 \\
\hline $27 / 2 / 2014$ & Varonis Systems Inc & New York & 105.60 & 100.00 & 0.82 \\
\hline $12 / 4 / 2000$ & Nuance Communications Inc & Massachusetts & -0.39 & 99.63 & 1.00 \\
\hline $19 / 9 / 2013$ & Rocket Fuel Inc & California & 108.40 & 93.45 & 0.91 \\
\hline $22 / 6 / 2016$ & Twilio Inc & California & 137.90 & 91.93 & 0.93 \\
\hline $5 / 10 / 2016$ & Coupa Software Inc & California & 113.07 & 84.89 & 0.93 \\
\hline $19 / 9 / 2013$ & FireEye Inc & California & 242.80 & 80.00 & 0.93 \\
\hline $27 / 1 / 2014$ & CymaBay Therapeutics Inc & California & 45.82 & 80.00 & 0.91 \\
\hline \multicolumn{6}{|c|}{ Panel B: Indicative List of Ten Companies Operating in Low PAI States } \\
\hline IPO Date & Company & State & $\begin{array}{l}\text { Money left on the } \\
\text { table (in million } \$ \text { ) }\end{array}$ & Initial Returns & PAI \\
\hline $24 / 4 / 2002$ & DOV Pharmaceutical Inc & New Jersey & -21.50 & -33.08 & 0.12 \\
\hline $2 / 11 / 2006$ & ORBCOMM Inc & New Jersey & -30.00 & -29.55 & 0.12 \\
\hline $18 / 11 / 2011$ & Digital Domain Media Group Inc & Florida & -9.10 & -21.76 & 0.19 \\
\hline $10 / 5 / 2011$ & FriendFinder Networks Inc & Florida & -84.48 & -21.50 & 0.19 \\
\hline $13 / 12 / 2011$ & Sanchez Energy Corp & Texas & -20.00 & -17.05 & 0.07 \\
\hline $5 / 3 / 2015$ & MaxPoint Interactive Inc & $\begin{array}{c}\text { North } \\
\text { Carolina }\end{array}$ & -11.31 & -15.13 & 0.06 \\
\hline $15 / 3 / 2001$ & SureBeam Corp(Titan Corp) & California & -1.71 & -14.06 & 0.10 \\
\hline $4 / 8 / 2015$ & Amplify Snack Brands Inc & Texas & -27.90 & -10.33 & 0.08 \\
\hline $25 / 5 / 2016$ & Cotiviti Holdings Inc & Georgia & -23.62 & -9.95 & 0.07 \\
\hline $16 / 1 / 2014$ & EP Energy Corp & Texas & -67.58 & -9.60 & 0.08 \\
\hline
\end{tabular}


Table 5: Top/Bottom IPO Issuers Based on the Level of Political Alignment Index (PAI)

This Table presents distributional statistics for a sample of 1,639 U.S. IPOs from 1 January 2000 to 31 December 2016. The IPOs are described by issue-year, whereas in panel B the IPOs are distributed by industry. IPO deals are retrieved from the Thomson ONE Banker database.

$$
\text { Panel A: Indicative Ten Companies Operating in a High PAI state }
$$

\begin{tabular}{|c|c|c|c|c|c|c|}
\hline $\begin{array}{l}\text { IPO } \\
\text { Date }\end{array}$ & Company & State & $\begin{array}{l}\text { Age at } \\
\text { IPO }\end{array}$ & PAI & Survivorship & PMC \\
\hline $30 / 3 / 2000$ & ArrowPoint Communications Inc & Massachusetts & 1.79 & 1.00 & 0 & 0 \\
\hline $23 / 9 / 2003$ & AMIS Holdings Inc & Idaho & 2.83 & 1.00 & 0 & 0 \\
\hline $27 / 3 / 2013$ & NV5 Holdings Inc & Delaware & 1.10 & 1.00 & 0 & 0 \\
\hline $31 / 7 / 2014$ & Loxo Oncology Inc & Connecticut & 0.69 & 1.00 & 0 & 0 \\
\hline $10 / 8 / 2010$ & MediaMind Technologies Inc & New York & 4.66 & 0.97 & 0 & 0 \\
\hline $9 / 1 / 2014$ & GlycoMimetics Inc & Maryland & 2.71 & 0.97 & 0 & 1 \\
\hline $12 / 11 / 2013$ & Chegg Inc & California & 1.95 & 0.93 & 0 & 1 \\
\hline $29 / 5 / 2002$ & Overstock.com Inc & Utah & 2.20 & 0.92 & 1 & 0 \\
\hline $11 / 12 / 2003$ & International Steel Group Inc & Ohio & 1.79 & 0.92 & 0 & 0 \\
\hline $7 / 10 / 2009$ & Omeros Corp & Washington & 2.40 & 0.92 & 1 & 0 \\
\hline \multicolumn{7}{|c|}{ Panel B: Indicative Ten Companies Operating in a Low PAI state } \\
\hline $14 / 4 / 2014$ & Paycom Software Inc & Oklahoma & 3.74 & 0.00 & 0 & 0 \\
\hline $17 / 12 / 2013$ & AMC Entertainment Holdings Inc & Kansas & 0.00 & 0.00 & 0 & 1 \\
\hline $21 / 3 / 2013$ & West Corp & Nebraska & 1.95 & 0.00 & 0 & 0 \\
\hline $15 / 2 / 2007$ & Salary.com Inc & Massachusetts & 4.61 & 0.00 & 0 & 0 \\
\hline $31 / 1 / 2000$ & SkillSoft Corp & New Hampshire & 3.56 & 0.00 & 1 & 0 \\
\hline $19 / 4 / 2012$ & Midstates Petroleum Co Inc & Oklahoma & 3.09 & 0.05 & 0 & 0 \\
\hline $26 / 6 / 2014$ & ServiceMaster Global Hldgs Inc & Tennessee & 2.77 & 0.06 & 0 & 1 \\
\hline $7 / 5 / 2008$ & Colfax Corp & Maryland & 2.40 & 0.06 & 1 & 1 \\
\hline $13 / 12 / 2011$ & Sanchez Energy Corp & Texas & 1.10 & 0.07 & 1 & 0 \\
\hline 4/5/2006 & Northstar Neuroscience Inc & Washington & 2.77 & 0.08 & 0 & 1 \\
\hline
\end{tabular}


Table 6: Top/Bottom IPO Industries Based on the Level of Political Alignment Index (PAI)

This Table reports an indicative list with ten industries operating in the top and bottom ten industries.

\section{Top 10 Industries}

Bottom 10 Industries

\begin{tabular}{ll|ll}
\hline \multicolumn{1}{c|}{ Industries } & PAI & Industries & PAI \\
\hline Defense & 0.89 & Chemicals & 0.46 \\
Shipping Contain & 0.74 & Trading & 0.45 \\
Fabricated Products & 0.73 & Machinery & 0.43 \\
Construction Mat & 0.70 & Almost Nothing & 0.42 \\
Printing and Pub & 0.69 & Utilities & 0.40 \\
Beer \& Liquor & 0.69 & Business Suppliers & 0.40 \\
Agriculture & 0.66 & Textiles & 0.38 \\
Aircraft & 0.64 & Recreation & 0.25 \\
Construction & 0.63 & Non-Metallic and & 0.24 \\
Candy \& Soda & 0.63 & Tobacco Products & 0.17 \\
\hline
\end{tabular}

Table 7: Top and Bottom Ten States Based on the Numbers of Survivors

This Table displays an indicative list with ten states based on the number of survivors.

Top 10 States Bottom 10 States

\begin{tabular}{lc|lc}
\hline \multicolumn{1}{c|}{ States } & Number of Survivors & States & Number of Survivors \\
\hline California & 204 & Alabama & 2 \\
Texas & 81 & Montana & 2 \\
Massachusetts & 54 & New Hampshire & 2 \\
Illinois & 35 & Wyoming & 2 \\
New York & 34 & Arkansas & 1 \\
Pennsylvania & 29 & Idaho & 1 \\
New Jersey & 27 & Iowa & 1 \\
Virginia & 24 & Mississippi & 1 \\
Colorado & 21 & North Dakota & 1 \\
Florida & 21 & West Virginia & 1 \\
\hline
\end{tabular}


Table 8: Summary Statistics of IPO Issuers Based on Political Activity

This Table presents the descriptive statistics based on whether a firm has Political Money Contributions (PMC) or not for a sample of 1,639 U.S. IPOs from 1 January, 2000 to 31 December, 2016. The number of PMC firms is 181.

\begin{tabular}{lccc}
\hline & PMC=0 & PMC=1 & Difference \\
\hline Underpricing & Mean & Mean & p-value \\
Firm Age & 20.95 & 16.19 & 0.0778 \\
Leverage & 2.20 & 2.19 & 0.4441 \\
Proceeds & 0.37 & 0.42 & 0.9316 \\
EPS & 4.39 & 5.23 & 0.0000 \\
VC & 0.45 & 0.52 & 0.9542 \\
Underwriter & 0.54 & 0.41 & 0.0007 \\
Internet & 0.38 & 0.61 & 0.0000 \\
Technology & 0.10 & 0.11 & 0.6695 \\
Nasdaq & 0.37 & 0.25 & 0.0007 \\
\hline
\end{tabular}

Table 9: Time effects of PAI on IPO First-Day Returns

This Table demonstrates the results of OLS regressions of PAI on IPO underpricing for along different political periods. The dependent variable, underpricing, is calculated as the percentage change from the first day closing price to offer price. Model (1) and (2) display the results when the administration is controlled from Democrats and Republicans. Model (3)-(6) present the findings of the influence of PAI on IPO returns for the election years, non-election years, before midterm elections and after midterm elections. Before midterm elections is equal to one if the IPO firm is issued within two years before the election date and zero otherwise. After midterm elections is equal to one if the IPO firm is issued within two years after the election date and zero otherwise. Control variables are: Company Age, Leverage, Proceeds, EPS, VC, Underwriter, Internet, Technology, Nasdaq, Overhang, Market Return, Real GDP Growth, Personal Income and Unemployment Rate Year, Industry and State Dummies. T-statistics are included in the parentheses, are adjusted for heteroskedasticity robust standard errors and clustered by state. $* * *, * *$, and $*$ denote significance at the $1 \%, 5 \%$, and $10 \%$ levels, respectively. All variables are defined in Appendix A.

\begin{tabular}{|c|c|c|c|c|c|c|}
\hline & $\begin{array}{c}\text { Democratic } \\
\text { administrations }\end{array}$ & $\begin{array}{c}\text { Republican } \\
\text { administrations }\end{array}$ & $\begin{array}{l}\text { Election years } \\
\text { (President) }\end{array}$ & $\begin{array}{c}\text { Non-election } \\
\text { years } \\
\text { (President) }\end{array}$ & $\begin{array}{l}\text { Before midterm } \\
\text { Elections }\end{array}$ & $\begin{array}{l}\text { After midterm } \\
\text { Elections }\end{array}$ \\
\hline & (1) & (2) & (3) & (4) & (5) & (6) \\
\hline PAI & $\begin{array}{c}23.60 * * \\
(3.39)\end{array}$ & $\begin{array}{l}10.30 \\
(1.45)\end{array}$ & $\begin{array}{l}13.50 \\
(1.55)\end{array}$ & $\begin{array}{c}2.85 * * * \\
(2.95)\end{array}$ & $\begin{array}{c}0.99 \\
(1.68)\end{array}$ & $\begin{array}{l}4.90 * * \\
(2.83)\end{array}$ \\
\hline Control Variables & $\mathrm{Y}$ & $\mathrm{Y}$ & $\mathrm{Y}$ & Y & $\mathrm{Y}$ & $\mathrm{Y}$ \\
\hline Year Fixed Effects & $\mathrm{Y}$ & $\mathrm{Y}$ & $\mathrm{Y}$ & $\mathrm{Y}$ & $\mathrm{Y}$ & $\mathrm{Y}$ \\
\hline $\begin{array}{c}\text { Industry Fixed } \\
\text { Effects }\end{array}$ & $\mathrm{Y}$ & $\mathrm{Y}$ & $\mathrm{Y}$ & $\mathrm{Y}$ & $\mathrm{Y}$ & $\mathrm{Y}$ \\
\hline State Fixed Effects & $\mathrm{Y}$ & $\mathrm{Y}$ & $\mathrm{Y}$ & $\mathrm{Y}$ & $\mathrm{Y}$ & $\mathrm{Y}$ \\
\hline State Cluster & $\mathrm{Y}$ & $\mathrm{Y}$ & $\mathrm{Y}$ & $\mathrm{Y}$ & $\mathrm{Y}$ & $\mathrm{Y}$ \\
\hline $\mathrm{N}$ & 702 & 822 & 486 & 1,038 & 721 & 711 \\
\hline Adjusted $R^{2}$ & 0.2162 & 0.3269 & 0.3365 & 0.1737 & 0.2024 & 0.1958 \\
\hline
\end{tabular}


Table 10: Endogeneity Control and Sample Selection Bias

This Table reports the relevant tests for endogeneity and sample selection bias. Panel A illustrates the average treatment effect of the treated for IPO issuers located in high and low PAI states controlling for the endogeneity of Political Alignment Index (PAI) using propensity score matching (PSM). The sample consists of initial public offerings from 2000 to 2016 in the US stock market. As for the binary feature of PAI (High PAI); if the PAI is above the median, then High PAI is set to 1 , otherwise is 0 . The outcome variable is IPO initial returns, calculated as the percentage changes from the first day closing price to offer price. The variables used for matching include: Firm Age, Leverage, Proceeds, EPS, VC, Underwriter, Internet, Technology, Nasdaq, Market Return, Real GDP Growth, Personal Income and Unemployment Rate Year, Industry and State Dummies. Panel B displays the effects of PAI on IPO first-day returns using the Heckman two-step treatment effect model. ***, **, and * denote significance at the 1\%, 5\%, and $10 \%$ levels, respectively. All variables are defined in Appendix A.

Panel A: Propensity Score Matching

\begin{tabular}{cc}
\hline & $(1)$ \\
& Initial Returns \\
\hline ATET & $7.83 * * *$ \\
(High PAI vs. Low PAI) & $(2.73)$ \\
$\mathrm{N}$ & 1,524 \\
\hline
\end{tabular}

Table 10: Endogeneity Control and Sample Selection Bias (continued) Panel B: Heckman Two-Step Treatment Effect Model of Political Alignment Index

\begin{tabular}{|c|c|c|}
\hline & $\begin{array}{l}\text { Selection } \\
\text { (1) }\end{array}$ & $\begin{array}{c}\text { Outcome } \\
\text { (2) }\end{array}$ \\
\hline PAI & & $\begin{array}{c}3.69 * * \\
(2.02)\end{array}$ \\
\hline Firm Age & $\begin{array}{c}0.13 * * * \\
(3.70)\end{array}$ & $\begin{array}{l}-3.37 \\
(-1.48)\end{array}$ \\
\hline Leverage & $\begin{array}{c}0.17 * * \\
(1.97)\end{array}$ & $\begin{array}{l}-5.13 \\
(-1.24)\end{array}$ \\
\hline Proceeds & $\begin{array}{c}-0.05 \\
(-1.24)\end{array}$ & $\begin{array}{l}4.28 * * \\
(2.30)\end{array}$ \\
\hline EPS & $\begin{array}{c}-0.39 * * * \\
(-5.17)\end{array}$ & $\begin{array}{c}11.39 * \\
(1.93)\end{array}$ \\
\hline Overhang & $\begin{array}{c}0.03 * * * \\
(3.95)\end{array}$ & $\begin{array}{c}1.15^{* * * *} \\
(3.92)\end{array}$ \\
\hline $\mathrm{VC}$ & $\begin{array}{c}-0.03 \\
(-0.37)\end{array}$ & $\begin{array}{c}14.67 * * * \\
(3.92)\end{array}$ \\
\hline Underwriter & $\begin{array}{c}0.09 \\
(1.14)\end{array}$ & $\begin{array}{c}2.94 \\
(0.76)\end{array}$ \\
\hline Internet & $\begin{array}{c}0.07 \\
(0.61)\end{array}$ & $\begin{array}{c}-2.43 \\
(-0.47)\end{array}$ \\
\hline Technology & $\begin{array}{c}-0.08 \\
(-1.04)\end{array}$ & $\begin{array}{c}13.84 * * * \\
(3.83)\end{array}$ \\
\hline Nasdaq & $\begin{array}{c}-0.06 \\
(-0.63)\end{array}$ & $\begin{array}{c}8.13 * * \\
(2.05)\end{array}$ \\
\hline Market Return & $\begin{array}{c}-0.27 * * * \\
(-3.87)\end{array}$ & $\begin{array}{c}-0.46^{* * *} \\
(2.38)\end{array}$ \\
\hline Real GDP Growth Rate & $\begin{array}{c}0.11 * * * \\
(6.78)\end{array}$ & $\begin{array}{c}0.90 \\
(0.56)\end{array}$ \\
\hline Personal Income & $\begin{array}{c}0.01 \\
(1.62)\end{array}$ & $\begin{array}{c}-0.01 \\
(-0.66)\end{array}$ \\
\hline Unemployment Rate & $\begin{array}{c}0.22 * * * * \\
(9.43)\end{array}$ & $\begin{array}{l}-4.45^{*} \\
(-1.72)\end{array}$ \\
\hline Inverse Mills Ratio & & $\begin{array}{l}-29.01 \\
(-1.40)\end{array}$ \\
\hline $\mathrm{N}$ & & \\
\hline
\end{tabular}


Figure 1: IPO Activity by State

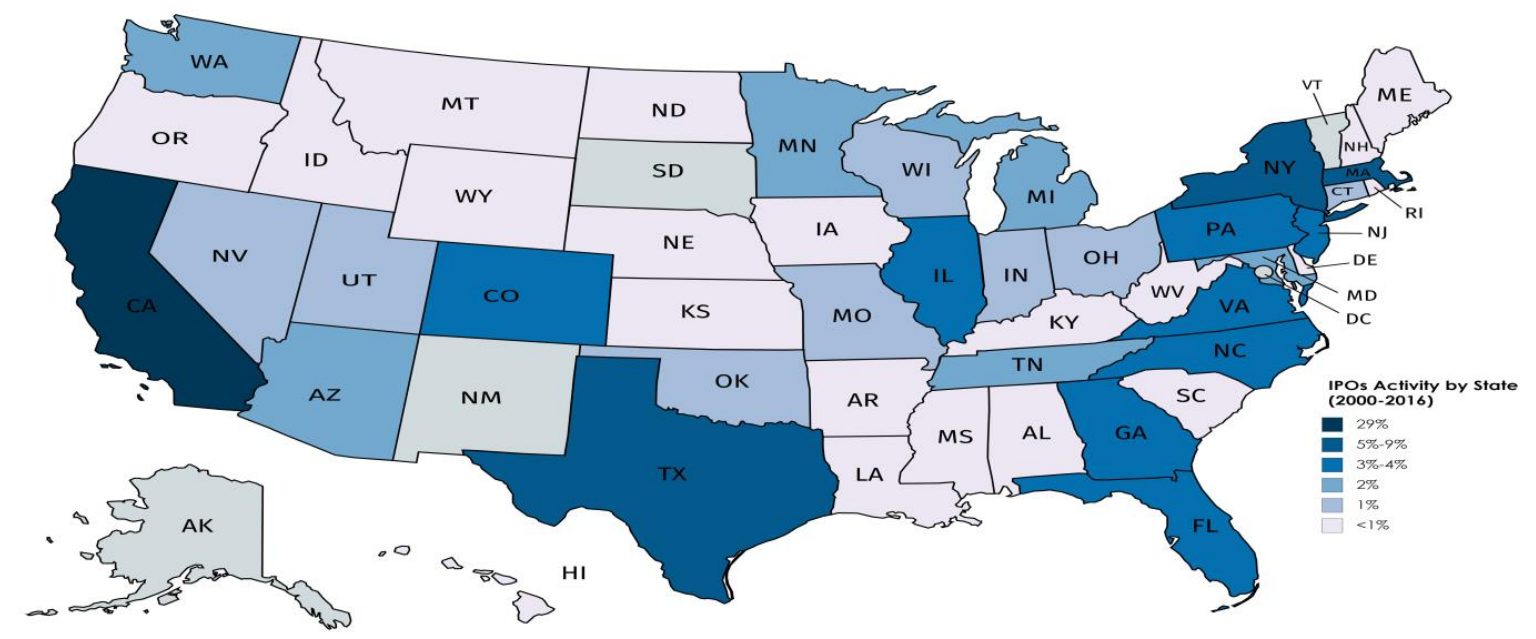

Figure 2: PAI Distribution by State (2000)

Figure 3: PAI Distribution by State (2004)
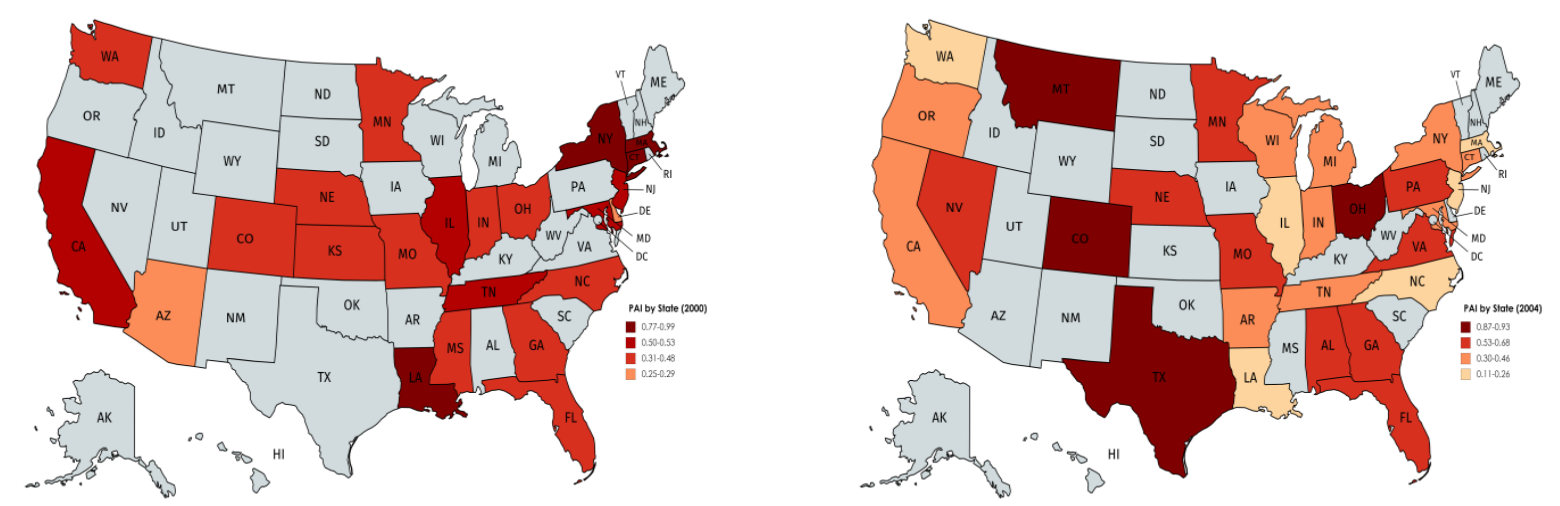

Figure 4: PAI Distribution by State (2008)

Figure 5: PAI Distribution by State (2012)
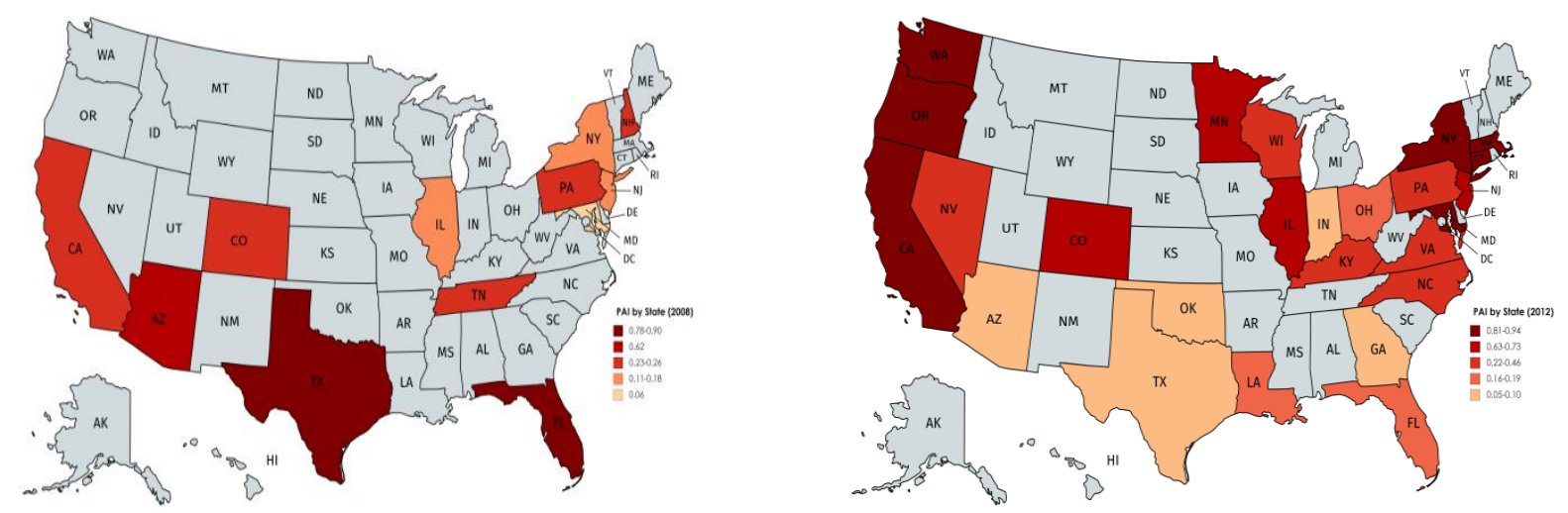
Figure 6: PAI Distribution by State (2016)

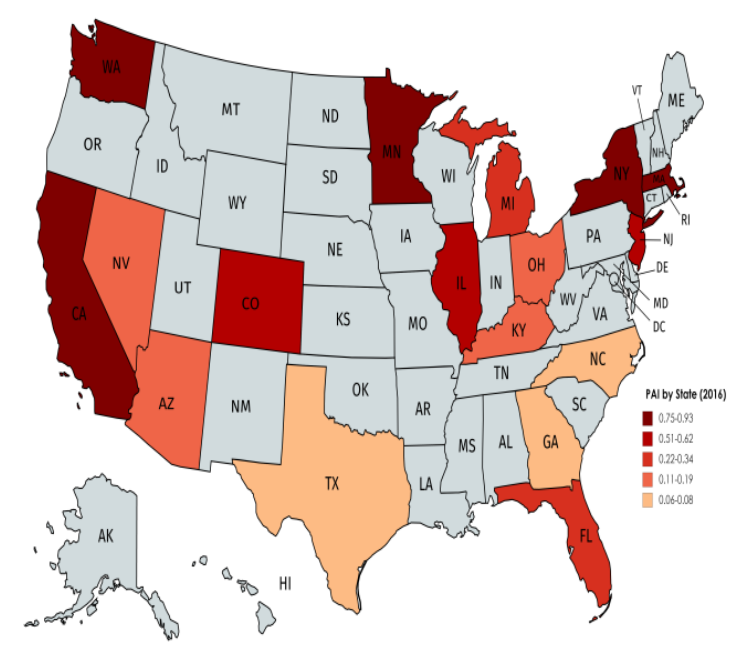

Figure 7: Breakdown of IPO PMC Expenditure by Type

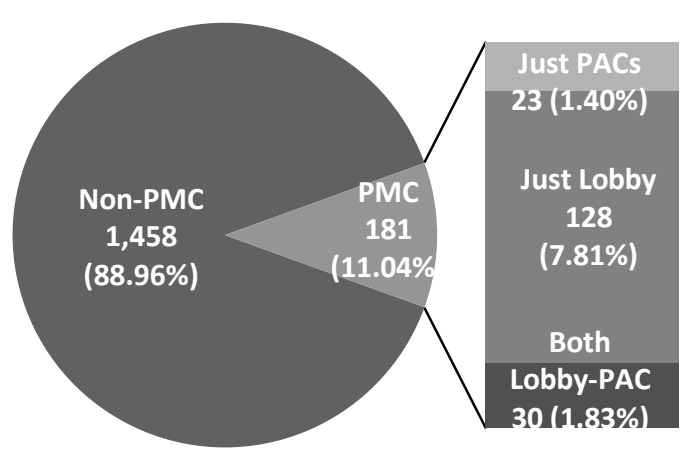

